\title{
Feedbacks of dust and boundary layer meteorology during a dust storm in the eastern Mediterranean
}

\author{
S. Rémy ${ }^{1,2}$, A. Benedetti ${ }^{2}$, A. Bozzo ${ }^{2}$, T. Haiden ${ }^{2}$, L. Jones ${ }^{2}$, M. Razinger ${ }^{2}$, J. Flemming ${ }^{2}$, R. J. Engelen ${ }^{2}$, V. H. Peuch ${ }^{2}$, \\ and J. N. Thepaut ${ }^{2}$ \\ ${ }^{1}$ Laboratoire de Météorologie Dynamique, Paris, France \\ ${ }^{2}$ European Centre for Medium-Range Weather Forecasts, Reading, UK \\ Correspondence to: S. Rémy (samuel.remy@ecmwf.int)
}

Received: 28 August 2014 - Published in Atmos. Chem. Phys. Discuss.: 13 November 2014

Revised: 14 September 2015 - Accepted: 5 November 2015 - Published: 20 November 2015

\begin{abstract}
Aerosols affect the atmosphere through direct interaction with short-wave and long-wave radiation and the microphysical properties of clouds. In this paper we report in detail on several mechanisms by which the short-term impact of dust on surface radiative fluxes can affect the dust loading of the atmosphere via modification of boundary-layer meteorology. This in turn affects the aerosol radiative forcing itself. Examples of these feedbacks between dust and boundary layer meteorology were observed during a series of dust storms in the Sahara and the eastern Mediterranean in April 2012. These case studies have been analysed using the Monitoring Atmospheric Composition and Climate - Interim Implementation (MACC-II) system.

The radiative fluxes in the short-wave and long-wave spectra were both significantly affected by the prognostic aerosol-radiation interaction, which in turn impacted the meteorological simulation. Reduced incoming solar radiation below the aerosol layers led to a decrease in maximum surface temperatures and to a more stable thermal stratification of the lower atmosphere. This in turn forced weaker surface wind speeds and eventually smaller dust emissions. Moreover, we also observed a secondary impact of the aerosol radiative forcing, whereby horizontal gradients of surface temperature were increased at the edge of the dust plume, which led to local increases of surface wind speeds due to the thermal wind effect. The differentiated impact of the aerosol layer on surface pressure also contributed to the increase in surface wind speed and dust production in the same area.

Enhanced long-wave radiative fluxes by the dust mass were associated with opposite processes. Less stable thermal stratification at night, brought mainly by higher minimum
\end{abstract}

temperatures at the surface, caused stronger surface winds. At the edge of the dust storm, weaker horizontal temperature and pressure gradients forced lower winds and reduced dust production.

Regarding dust emissions, short-wave radiative forcing had a larger impact than long-wave radiative forcing, corroborating several previous studies. For surface temperature, short-wave and long-wave contribution were close in intensity.

These feedbacks were amplified when using data assimilation to build the aerosol analysis of the MACC-II global system. This led to an improvement in the short-term forecasts of thermal radiative fluxes and surface temperatures.

\section{Introduction}

\subsection{Aerosol impacts on meteorology}

Aerosol particles play an important role in the atmosphere through various mechanisms. They impact air quality and represent a serious public health issue, as shown by recent particulate matter (PM) pollution events in western Europe and China (Zhang et al., 2014; Sun et al., 2013). Aerosol particles also influence the atmospheric radiative budget directly by scattering and absorbing short-wave and long-wave radiation (aerosol direct effect; e.g. Yu et al., 2006; Bellouin et al., 2005), and indirectly affecting the concentration, size and chemical composition of the cloud condensation nuclei $(\mathrm{CCN})$, which in turn impacts the life cycle, the optical prop- 
erties and the precipitation activity of clouds (Koch and Del Genio, 2010; Painemal and Zuidema, 2013; Hoose and Möhler, 2012; Niemand et al., 2012).

The aerosol direct effect consists of the sum of two phenomena: scattering/absorption of incoming solar radiation and absorption/emission of long-wave radiation. The former reduces the amount of solar energy that reaches the surface and can cause a warming of the aerosol layer because of absorption. Aerosols also absorb and re-emit long-wave radiation, which increases downwelling long-wave radiation in and below the aerosol layer, and reduces night-time cooling of the surface. An aerosol layer thus acts on the radiative budget at the surface and in the lower atmosphere similar to a thin layer of clouds. The radiative impact of aerosols is very dependent on their vertical distribution and surrounding environment: Choi and Chung (2014) showed that whether the aerosol layer is below or above a cloud layer will impact their radiative impact on the surface and on the atmosphere by an order of magnitude.

Mineral dusts are produced in arid or semi-arid areas and lifted into the atmosphere, if surface winds are strong enough, through the saltation process (Marticorena and Bergametti, 1995). Global emissions are estimated by numerical models to be in the range of 500 to $4400 \mathrm{Tg}$ per year (Huneeus et al., 2011). The large spread in emissions estimate reflects the fact that no observations of the dust emission amount are available. Out of the global amount, the Sahara desert contributes an estimated 400 to $2200 \mathrm{Tg}$ per year. Major dust outbreaks frequently affect the Mediterranean, the Red Sea and the Atlantic: an estimated 20-30 Tg of dust is deposited each year in the Amazon Basin and contributes to the fertilization of the Amazon Basin (Yu et al., 2015).

Most climate models now include aerosols and take into account their radiative impact on the atmosphere (Bellouin et al., 2011). For short-term forecasts by operational numerical weather prediction (NWP) models, Tompkins et al. (2005) and Rodwell and Jung (2008) both showed the improvement brought by more realistic aerosol climatologies on the forecasts from European Centre for Medium-Range Weather Forecasts (ECMWF) operational model. Mulcahy et al. (2014) investigated several configurations for the inclusion of interactive aerosol direct and indirect effects in the Met Office Unified Model (MetUM) and managed to correct a significant bias in the outgoing long-wave radiative fluxes over the Sahara that was diagnosed by Haywood et al. (2005).

Mineral dusts and their short-term impacts on the atmosphere have been the subject of intensive studies (e.g. Perez et al., 2006; Stanelle et al., 2010; Spyrou et al., 2013), using numerical models developed by Tegen and Lacis (1996), Nickovic et al. (2001) and Woodward (2001) among others. Several results are summed up in Miller et al. (2014), who emphasize the diversity of the results obtained in terms of radiative forcing by mineral dust. Miller et al. (2004) and Perez et al. (2006) described a feedback between total aerosol forcing and atmospheric stability whereby lower sur- face temperatures increased atmospheric stability, thus decreasing surface winds and dust production. This feedback was also noted in Ahn et al. (2007). Heinold et al. (2008) investigated the impact of dust radiative forcing on nocturnal low-level jets (NLLJs) and found a local increase in intensity of NLLJs caused by a more stable boundary layer.

This work focus on short-term radiative effects of dust. It aims first to complete the description of the dust-radiation feedback by Perez et al. (2006) and Miller et al. (2004) by decomposing the feedback into two components driven by dust forcing on short-wave radiation and long-wave radiation respectively. Our objective is also to identify other aerosolsboundary layer meteorology interactions. One of the objectives of this study is to compare the results of an experimental version of the Monitoring Atmospheric Composition and Climate - Interim Implementation (MACC-II) system, which uses radiatively interactive aerosols, with the pre-operational setup, which uses an aerosol climatology to compute dustradiation interaction.

We analyse the various feedbacks between the radiative impact of dust on the short-wave and long-wave spectra and boundary layer meteorological processes, comparing experiments with prognostic aerosol fields against experiments with a climatological distribution. The interaction of prognostic aerosols and meteorology is included at first only in the forward model, without any impact on the meteorological initial conditions. In a second step, we add them also in the aerosol assimilation system so that the initial conditions of dust also take into account the impact of this interaction.

\subsection{The MACC global atmospheric composition forecasting system}

The Monitoring Atmospheric Composition and Climate - Interim Implementation (MACC-II) is a European-funded program that aims to monitor and forecast atmospheric composition. It is the precursor of the broader Copernicus Atmosphere Monitoring Service. The aim of MACC-II is to create and operate an assimilation and forecasting system for monitoring aerosols, greenhouse gases and reactive gases, using satellite observations and a combination of global and regional models (Hollingsworth et al., 2008; Peuch and Engelen, 2012). The MACC-II global system is based on the Integrated Forecast System (IFS) meteorological model, maintained and developed by ECMWF; the version used in this work corresponds to cycle 40R1 of the IFS for which a detailed description can be found at https://software.ecmwf.int/ wiki/display/IFS/CY40R1+Official+IFS+Documentation.

Aerosols are forecasted within the MACC-II global system by a forward model (Morcrette et al., 2009, based on earlier work by Reddy et al., 2005 and Boucher et al., 2002) that uses five species: dust, sea salt, black carbon, organic carbon and sulfates. Dust aerosols are represented by three prognostic variables that correspond to three size bins, with bin limits of $0.03,0.55,0.9$ and $20 \mu \mathrm{m}$. The main processes 
that are taken into account are the production of dust, through saltation, and the removal of dust, by wet and dry deposition and sedimentation. The areas likely to produce dust are diagnosed as a function of surface albedo, moisture of the first soil level and bare soil fraction. Dust emissions are then parameterized, following Ginoux et al. (2001), as a function of the cubic power of $10 \mathrm{~m}$ wind speed. Dry deposition depends on a prescribed deposition velocity and on aerosol concentration in the lowermost model level above the surface. Sedimentation is currently applied only to the largest dust bin and depends on a fixed settling velocity and the concentration at each model level. Scavenging did not occur during the period under scrutiny since there were very little clouds and no rain at all.

In the pre-operational version of the global MACC-II system, the radiative impact of aerosols is taken into account using the aerosol monthly climatology of Tegen et al. (1997). In an experimental version of the model, the aerosol direct effect can be computed from the mass mixing ratio of the prognostic aerosols provided by the MACC aerosol module. The computation of the radiative impact of aerosols was modified for this study so that it is now possible to activate only the short-wave or the long-wave components of the aerosol direct effect separately.

The radiative impact of the aerosols in the radiative transfer code of the ECMWF model is parameterized as function of the mass-extinction coefficient $(k)$, single-scattering albedo $(\omega)$ and asymmetry parameter $(g)$ for the shortwave, while only the emission from the aerosol layer is considered in the longwave and the scattering is neglected. These optical properties are available from look-up tables computed offline for the spectral bands of the radiation code (Morcrette et al., 2009). This introduces an additional source of uncertainty as the refractive indices for mineral dust have been highlighted as the single most important factor for the large uncertainty in the radiative impact of mineral dust (Myhre and Stordal, 2001).

In MACC two sets of optical properties are available. One is derived from the refractive index used in the Hadley Centre climate model (Woodward, 2001), which is a compilation of refractive indices estimated from various measurements (Carlson and Benjamin, 1980; Sokolik et al., 1993, 1998; WMO, 1983). Another is based on the refractive index detailed in Fouquart et al. (1987). Highwood et al. (2003) suggests the use of the refractive index from Fouquart et al. (1987) as it appears to give a better agreement with the observations from the SHADE field campaign. This set of refractive index was also used in Myhre et al. (2003). Our experiments were carried out using both refractive indices but we will report only the results using the Fouquart et al. (1987) aerosol model. Results using the Woodward (2001) refractive index are close to this situation and do not contradict the conclusions reached in this paper. The optical properties are computed for each size bin using a standard Mie scattering algorithm (Ackerman and Toon, 1981), hence assuming
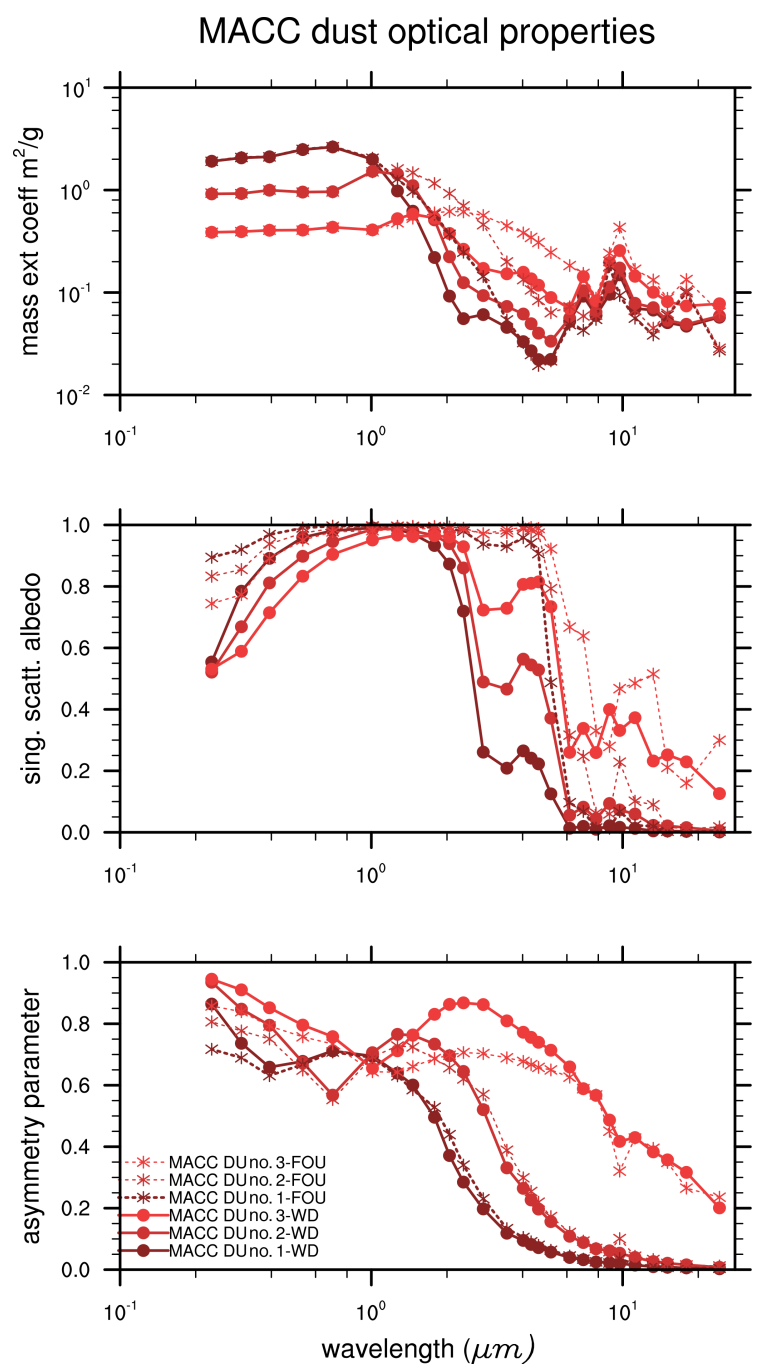

Figure 1. Dust optical properties used in the MACC system: mass extinction coefficient (top), single-scattering albedo (middle) and asymmetry parameter (bottom) as a function of wavelength for the three dust bins (no. 1 is the smallest bin, no. 3 is the largest), computed using the refractive indices of Woodward (2001) and Fouquart et al. (1987).

spherical particles. Mishchenko et al. (1997) show that assuming spherical particles for mineral dust introduces only a modest uncertainty in the calculation of radiative fluxes. The dust optical properties used in the MACC system for each dust bin are detailed in Fig. 1. They can be compared to Fig. 1 of Spyrou et al. (2013) and Fig. 1 of Perez et al. (2006).

The global MACC-II forecasting system provides aerosol analysis by assimilating total aerosol optical depth (AOD) observations provided by the Moderate Resolution Imaging Spectroradiometer (MODIS) instruments on-board NASA polar orbiting satellites Aqua and Terra in a 4D-Var assimilation algorithm, as described in Benedetti et al. (2009). The product used in the assimilation step is the Dark Target retrieval; hence it is not available in regions with high surface 
albedo, such as desert areas. MODIS Deep Blue product, aimed at bright surfaces, is now used in the most recent version of the system.

\subsection{Evaluating aerosol impacts on numerical weather prediction: WGNE model intercomparison}

The Working Group on Numerical Experimentation (WGNE) was jointly established by the Commission for Atmospheric Sciences of the World Meteorological Organization (WMO) and the World Climate Research Programme (WCRP). It has the responsibility of fostering the development of atmospheric circulation models for use in weather, climate, water and environmental prediction on all timescales and diagnosing and resolving shortcomings of these models. WGNE has recently launched a model intercomparison (Freitas, 2015) aimed at improving the understanding of aerosol impacts on numerical weather prediction. Three case studies were proposed to the participants: a severe anthropogenic pollution case in January 2013 in northern China, a biomass-burning event in Brazil in September 2012 and a dust storm over Egypt on 18 April 2012. This paper focuses on the dust episode of 18 April 2012 over the eastern Mediterranean but we also include the analysis of another dust storm, which took place on 12 and 13 April 2012 in the central Sahara region, as more ground observations were available.

\section{Dust episodes of April 2012 in the Sahara and eastern Mediterranean}

\subsection{Available observations}

Surface observations of meteorological parameters are available in Algeria and Egypt but not over Libya. Analyses from the operational ECMWF model were also used.

Observations are much sparser for radiative fluxes than for meteorological parameters. The Baseline Surface Radiation Network (BSRN) (Heimo et al., 1993) maintains two stations in the area of interest: Tamanrasset (Mimouni, 2013) in southern Algeria and Sede Boqer in Israel (Lyubansky, 2012). Unfortunately, observations from Sede Boqer were not available in April 2012. Downwelling surface flux of short-wave and long-wave radiation at Tamanrasset, in southern Algeria, were measured with a frequency of $1 \mathrm{~min}$.

Finally AOD observations were available from the AErosol RObotics NETwork (AERONET, Holben et al., 1998) of ground observations. The stations used in this study are Tamanrasset, collocated with radiative fluxes observation from BSRN, and Cairo in Egypt. As these observations are provided by sun photometers, they are available only during the day. To supplement the absence of AOD observations at some stations, simulated AOD was also plotted to provide a qualitative assessment of the presence of dust. Total AOD ob- servations are also available from MODIS over desert areas, using the Deep Blue algorithm (Shi et al., 2013).

\subsection{Sahara dust storms of April 2012: synoptic evolution}

Dust storms are a frequent occurrence in the Sahara, where dust production areas are widespread. As the soil is generally very dry in these regions and predominantly composed of sand, surface temperatures can reach very high values in April. Higher altitude colder air from Mediterranean lows occasionally affects the area. The severe dust storm that affected Libya, Egypt and most of the eastern Mediterranean Basin on 17-18 April 2012 was produced by the conjunction of a deep low circulating over the Mediterranean and of a heat low that originated over western Libya-eastern Tunisia on 16 April 2012, caused by very high temperatures over the desert areas. Figure 2 shows mean sea-level pressure analyses over the northern Sahara and southern Mediterranean from 17 to 19 April 2012. The merging and interaction of the heat low and the Mediterranean low that is associated with mid-tropospheric colder air is clearly shown. This interaction, and the development of a powerful anticyclone over the central Sahara, led to the rapid deepening of a low between Crete and Greece on 18 April. The heat low moved in a north-easterly direction, left western Egypt in the night of 17 to 18 April and was then absorbed by the larger and fast moving Mediterranean low, which then moved quickly towards the north on 19 April 2012.

The synoptic situation led to high and sustained winds on 17-18 April over north-east Libya and Egypt associated with a cold front crossing these regions, reaching 11 to $14 \mathrm{~m} \mathrm{~s}^{-1}$ for more than $24 \mathrm{~h}$, according to model forecasts and observations. This led to the suspension of a very high load of dust, with AOD reaching 4.5 in Cairo at noon on 18 April. Besides the dust plume, the sky was entirely clear over Egypt and Libya during 17 and 18 April, which makes these 2 days a perfect case study for aerosol-radiation interaction.

The interaction between dust and the synoptic situation is shown by Fig. 3, which shows daily AOD over eastern Sahara from the Deep Blue algorithm applied to MODIS/Aqua observations. The large dust load that was lifted by the cold front associated with the heat low was then advected northwards by the deep Mediterranean low, towards Israel, Turkey and the eastern Mediterranean on 18-19 April 2012.

Figure 4 shows the evolution of the dust storm as analysed and forecasted by the MACC-II system, from 17 April 2012, 06:00 UTC, to 18 April 2012, 12:00 UTC. Dust AOD reaches very high values, locally above 4 . The area with AOD above 1 is very large throughout the storm.

This dust storm was preceded by another event between 11 and 15 April 2012, that affected the central Sahara up to Libya and western Egypt. This was caused by a persistent and slow-moving heat low over central Sahara combined with a deep low over western-central Mediterranean. This 


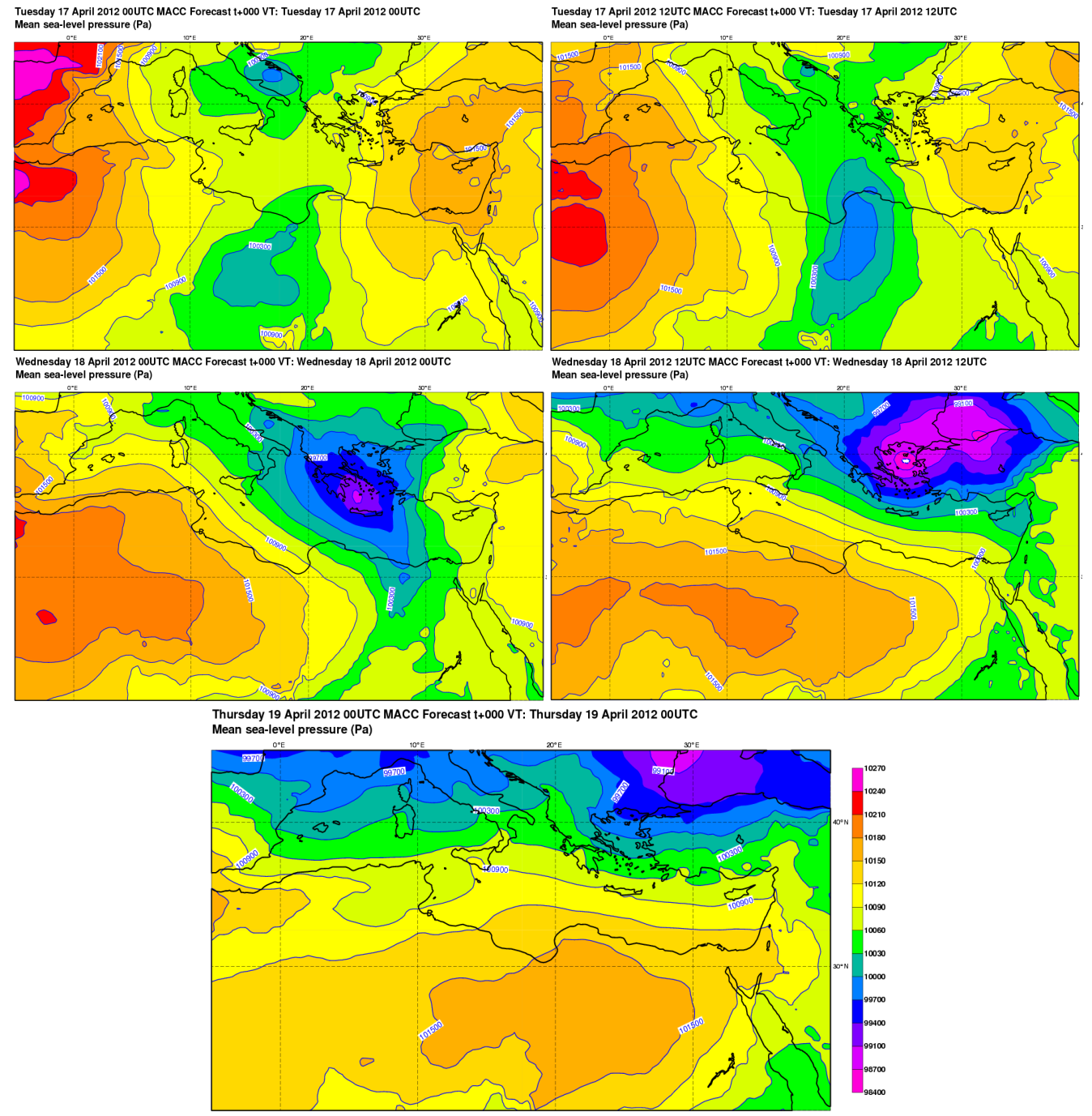

Figure 2. Analysis of mean sea-level pressure over the northern Sahara and southern Mediterranean from 17 April 2012, 00:00 UTC, to 19 April 2012, 00:00 UTC.

second event allowed forecasts of radiative fluxes to be compared against ground observations at Tamanrasset (Algeria), which was affected by the dust storm of 11 to 15 April but not by the subsequent storm of 17-18 April 2012.

\section{Methodology}

The objective of this study is to assess the impact of the aerosol direct effect on the forecasted meteorological parameters during the dust storms that affected the Sahara and eastern Mediterranean Basin in April 2012. To achieve that, the MACC-II global system was run with no dust aerosols, with the aerosol direct effect estimated from a climatology, i.e. in its pre-operational configuration, and with the aerosol direct effect estimated from prognostic aerosols. All runs were carried out with a $T_{L} 511$ horizontal spectral resolution which corresponds to a grid-box size of about $40 \mathrm{~km}$. 60 vertical hybrid sigma-pressure levels were used, the lowest level being $17 \mathrm{~m}$ above the surface. The time step was $900 \mathrm{~s}$.

\subsection{Cycling forecasts}

In this configuration, the model is run without assimilating AOD. The meteorological fields are initialized from the global MACC-II analysis, and the aerosol fields were initialized from the MACC reanalysis on 10 April 2012 only, and on later days from the previous $24 \mathrm{~h}$ forecast. The aerosol fields of analysis are not constrained by any observations and could drift away from observed values.

The main advantage of cycling forecast simulations comes from comparing the model outputs with and without radiatively interactive aerosols. Since the meteorological analyses are the same for all the experiments, the differences between 

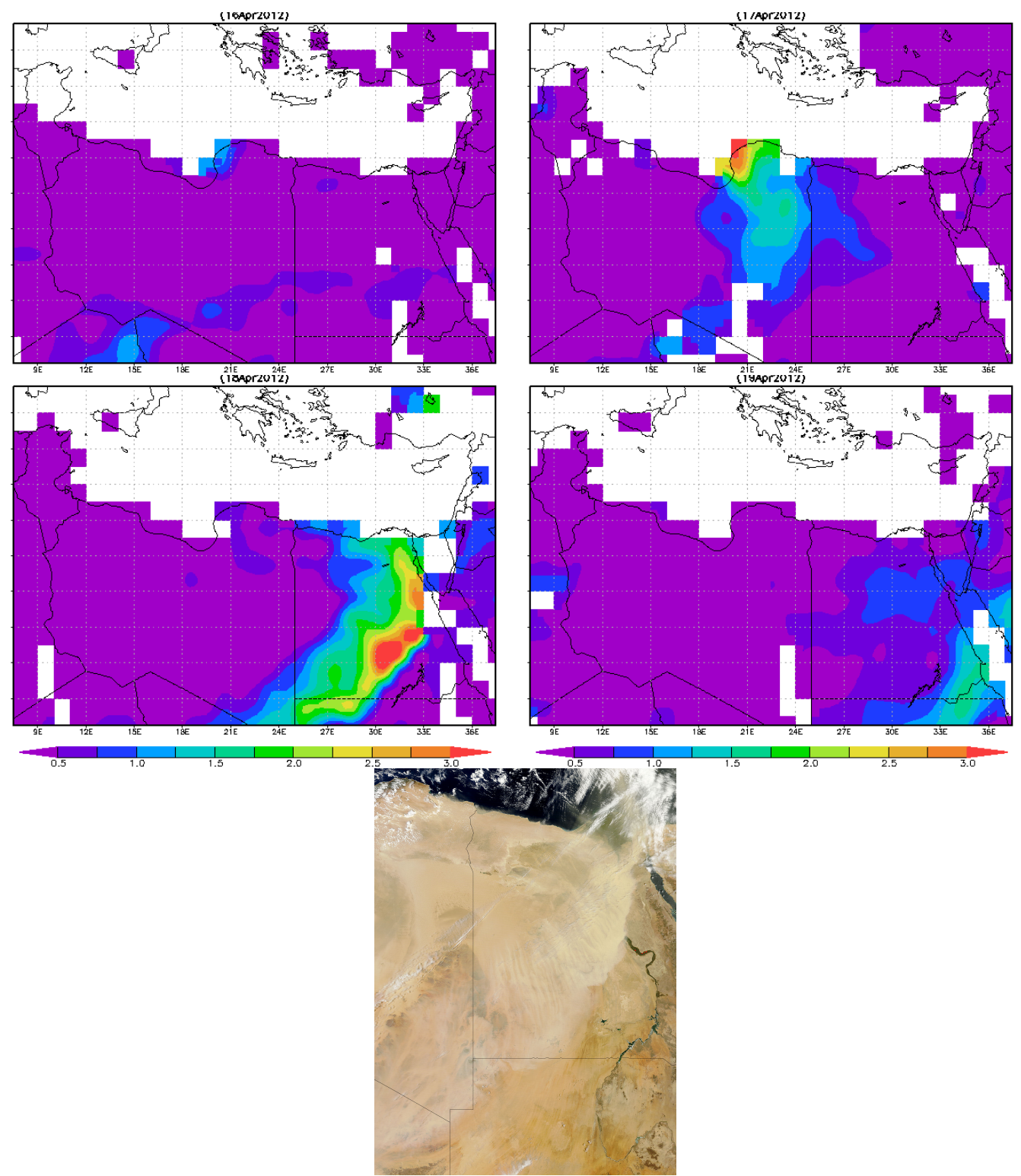

Figure 3. AOD at $550 \mathrm{~nm}$ from MODIS on Aqua, Deep Blue algorithm, daily average for 16, 17, 18 and 19 April 2012. Below: visible image from MODIS/Terra acquired on 18 April 2012 at 09:00 LT. Source: http://modis.gsfc.nasa.gov/gallery/individual.php?db_date=2012-04-22.

the meteorological forecasts originate only from the way that interaction between aerosols and radiation is computed, i.e. using prognostic aerosols or a climatology. Cycling forecasts are thus adequate to assess the aerosols' impact on forecasted meteorological fields.

A default for this configuration is that since the meteorological analyses are provided by another simulation, in this case by the MACC-II near-real-time (NRT) system, the interaction between aerosols and meteorology is reset at every forecasting cycle. Experiments were carried out with both aerosols and meteorological fields initialized from the previous $24 \mathrm{~h}$ forecast, and they showed the same qualitative results as when meteorological fields were initialized from the global MACC-II analysis. The amplitude of the aerosol-meteorology interaction was however significantly larger since it was also included in the meteorological analysis.

Cycling forecasts were carried out for the period from 10 to 30 April 2012, every $24 \mathrm{~h}$, with runs starting at 00:00 UTC.

We will analyse the prognostic aerosol direct effect (or "total aerosol effect") and also separately the short-wave and the long-wave aerosol radiative forcing. In particular, we performed the following experiments with cycling forecasts:

- NOAER: experiment with no dust aerosols; 

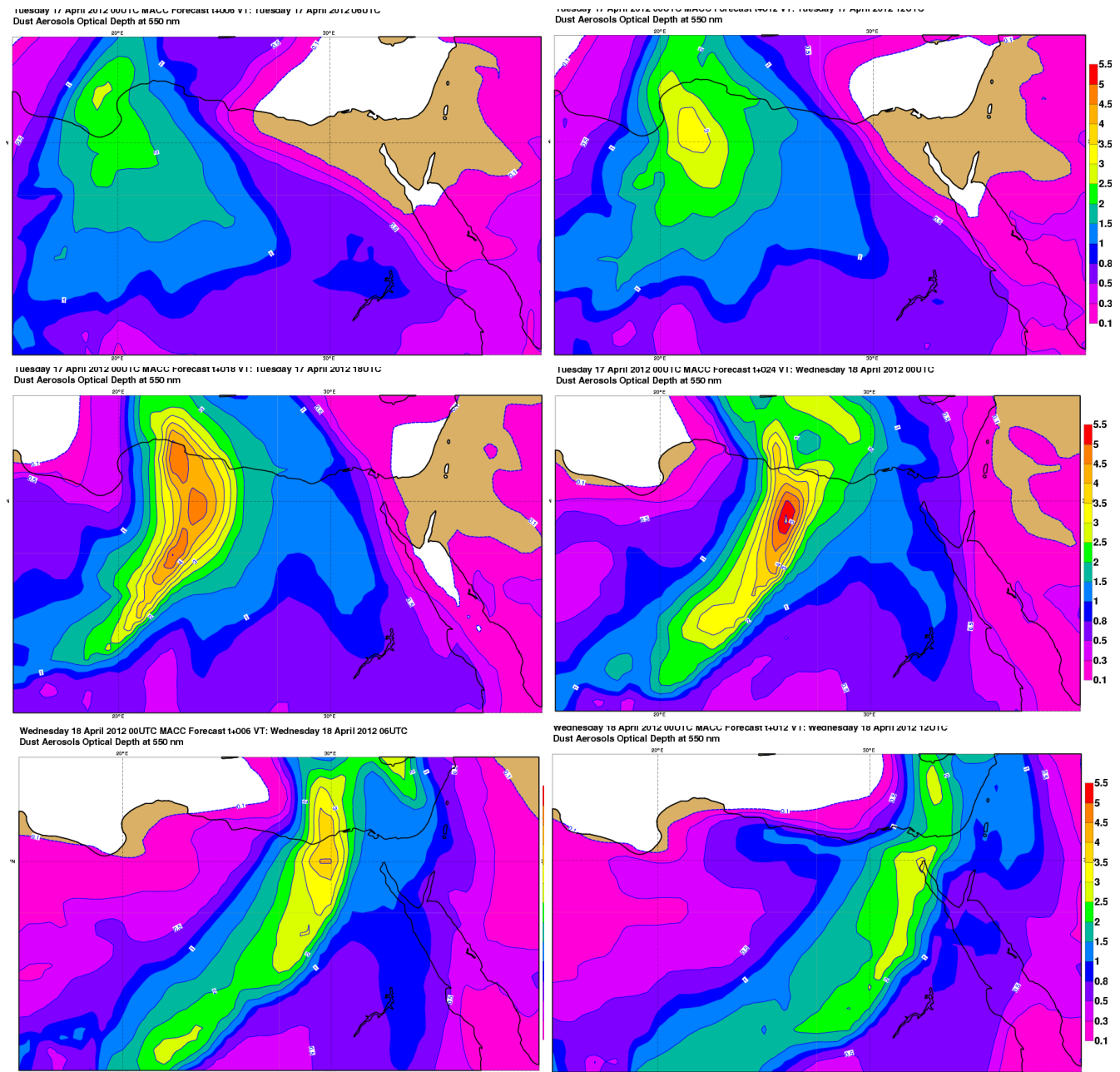

Tuesday 17 April 2012 oouTC MACC Forecast $1+024$ VT: Wednesday 18 April 2012 oouTC
$2 m$ temperature (K)
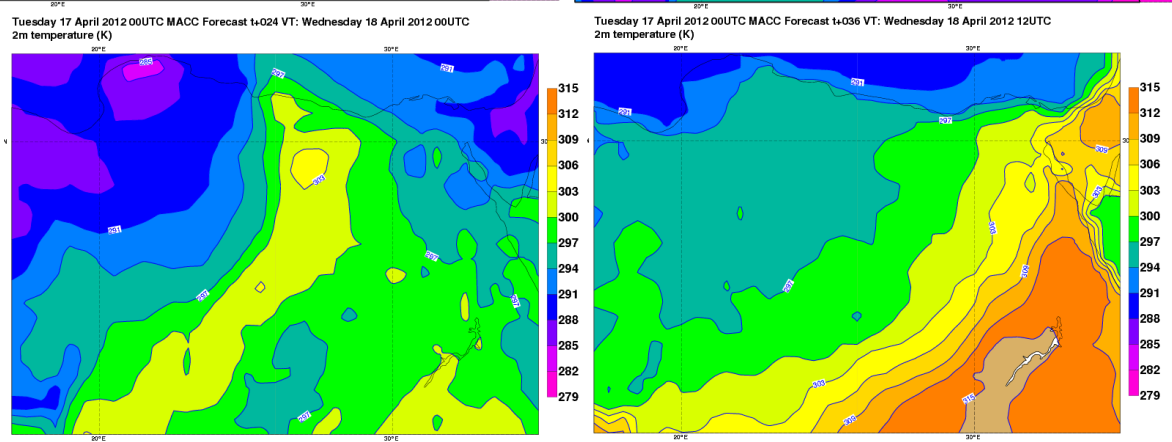

Figure 4. AOD at $550 \mathrm{~nm}$ from 17 April 2012, 06:00 UTC (top left), to 18 April, 12:00 UTC (middle bottom right); REF experiment starting on 17 April 2012, 00:00 UTC, and 18 April 2012, 00:00 UTC. At the bottom: simulation starting on 17 April 2012, REF experiment for $2 \mathrm{~m}$ temperature; $24 \mathrm{~h}$ forecast time (left), $36 \mathrm{~h}$ forecast time (right).

- REF: reference experiment with the aerosol direct effect computed from an aerosol climatology;

- Longwave (LW): the long-wave component of the aerosol direct effect is computed using prognostic aerosols, the short-wave part is computed with an aerosol climatology;
- Shortwave (SW): the short-wave component of the aerosol direct effect is computed using prognostic aerosols, the long-wave part is computed with an aerosol climatology;

- TOTAL: both the short-wave and the long-wave components of the aerosol direct effect are computed using prognostic aerosols. 


\subsection{Assimilation runs}

In this configuration the model is run with the full 4D-Var data assimilation, providing initial conditions for both the aerosol and meteorological variables. The following experiments were carried out with assimilation runs:

- REF_ASSIM: reference experiment with the aerosol direct effect computed from an aerosol climatology;

- TOTAL_ASSIM: the aerosol direct effect is computed using prognostic aerosols.

Runs were carried out at 00:00 and 12:00 UTC every day for the whole of April 2012, with an assimilation window of $12 \mathrm{~h}$. However, only the runs of 00:00 UTC go beyond $12 \mathrm{~h}$ of forecast time. As a follow-up to cycling forecasts, assimilation runs will allow the following to be studied: how using radiatively interacting aerosols in the forward model affects initial conditions through the data assimilation.

Table 1 provides a summary and a short description of the experiments carried out.

\section{Impact of dust on radiative fluxes}

In this section, forecasts of the REF and TOTAL experiments are evaluated against ground observations of radiative parameters. The TOTAL experiment is also compared to NOAER to assess the impact of aerosols on the radiative fluxes for this situation.

First, NOAER and REF experiments are compared to check the impact of the Tegen aerosol climatology on radiative fluxes. This climatology provides rather small values of dust AOD for this period, close to 0.3, and the impact on radiative fluxes is also rather small: in the order of $1 \mathrm{~W} \mathrm{~m}^{-2}$ for long-wave fluxes and $20-30 \mathrm{~W} \mathrm{~m}^{-2}$ for shortwave fluxes (not shown). Maximal and minimal temperatures are marginally impacted by this radiative forcing, by around 0.1 to $0.2 \mathrm{~K}$.

Looking at the time series of surface parameters measured at Tamanrasset and Cairo (Fig. 5), we can see that Tamanrasset was mostly affected by the dust storm from 12 to 14 April; high clouds were also present at times from 10 to 13 April. Cairo was impacted by high dust load mainly on 15 and 18 April.

Aerosols and clouds both impacted radiative fluxes on 1013 April at Tamanrasset. Observations of the diffuse and direct components (not shown) of downward solar surface flux (DSSF) show a decrease of up to $400-500 \mathrm{~W} \mathrm{~m}^{-2}$ for the direct component, matched by an increase of up 200 to $300 \mathrm{~W} \mathrm{~m}^{-2}$ for the diffuse component during this period. Total solar radiation was 200 to $300 \mathrm{~W} \mathrm{~m}^{-2}$ smaller on 12 and 13 April compared to 14-18 April. Observed downward long-wave fluxes at the surface were on average around $60 \mathrm{~W} \mathrm{~m}^{-2}$ higher than simulated on these 2 days. Since this is true for both REF and TOTAL, a bias in the model cloud cover is the likely cause.

Long-wave downward radiation forecasted by TOTAL was $10-20 \mathrm{~W} \mathrm{~m}^{-2}$ larger than with REF on 12-13 April at Tamanrasset, and $20-30 \mathrm{~W} \mathrm{~m}^{-2}$ larger on 15 and 18 April at Cairo, showing that the aerosol burden provided by the aerosol scheme was greater than the values given by the Tegen climatology. This reduced a negative bias of more than $20 \mathrm{~W} \mathrm{~m}^{-2}$ (for REF) in the forecasted long-wave fluxes at Tamanrasset. The DSSF was lower with TOTAL by 50 to $100 \mathrm{~W} \mathrm{~m}^{-2}$ on 12-13 April at Tamanrasset, and by more than $250 \mathrm{~W} \mathrm{~m}^{-2}$ on 18 April at Cairo, reflecting the total extinction effect by the aerosol layer. On 14, 16 and 17 April, at Tamanrasset, the predicted dust AOD was very low, lower than the values provided by the Tegen climatology: this was reflected in the slightly higher forecasted DSSF by TOTAL on these days.

At the top of the atmosphere (TOA), outgoing long-wave radiation (OLR) was smaller for TOTAL by $5-10 \mathrm{~W} \mathrm{~m}^{-2}$ on 12-13 April at Tamanrasset and by up to $20 \mathrm{~W} \mathrm{~m}^{-2}$ at Cairo. The order of magnitude in OLR difference between REF and TOTAL is in agreement with the results of Haywood et al. (2005) and Mulcahy et al. (2014). The difference is most important during daytime because, in the absence of clouds, OLR is driven mainly by surface temperature, which was lower for TOTAL as compared to REF. The overall impact of prognostic aerosols was rather small: on average, the OLR at TOA was only $2-3 \mathrm{~W} \mathrm{~m}^{-2}$ smaller for TOTAL. Short-wave radiation was also smaller at TOA for TOTAL because of increased columnar absorption over the bright desert surface. The difference reached $30-50 \mathrm{~W} \mathrm{~m}^{-2}$ at Tamanrasset on $12-$ 13 April and more than $150 \mathrm{~W} \mathrm{~m}^{-2}$ at Cairo on 18 April. On average, short-wave radiation at TOA was $14-16 \mathrm{~W} \mathrm{~m}^{-2}$ lower for TOTAL. The values for the aerosol forcing in the shortwave and in the longwave are consistent with Perez et al. (2006).

The short-wave forcing at the surface reached $-300 \mathrm{~W} \mathrm{~m}^{-2}$ at the heart of the dust storm (Fig. 6), and between -25 and $-75 \mathrm{~W} \mathrm{~m}^{-2}$ at TOA with a minimum of $-150 \mathrm{~W} \mathrm{~m}^{-2}$. These values are in agreement with values found in Perez et al. (2006), Heinold et al. (2008), Han et al. (2013) and Jish Prakash et al. (2015) (the latter study uses the same dust emission scheme as this study) for the surface values. At TOA, this study found mostly negative values above the dust storm during the day, and positive during the night, as opposed to positive values in the cited studies (except for Heinold et al., 2008, whose results are consistent with the results presented here). This could be caused by differences in single-scattering albedo and in the surface reflectivity. This could also be due to the fact that after $36 \mathrm{~h}$ of forecast time, the dust storm was located above the slightly darker surfaces of central and eastern Egypt; the dust plume was then brighter than the surface underneath, as shown by Fig. 3. The long-wave forcing was larger for $24 \mathrm{~h}$ than for $36 \mathrm{~h}$ of forecast time, because the dust load 
Table 1. Summary of the experiments carried out.

\begin{tabular}{llll}
\hline Name & Short description & $\begin{array}{l}\text { SW dust-radiation computed } \\
\text { with }\end{array}$ & $\begin{array}{l}\text { LW dust-radiation } \\
\text { puted with }\end{array}$ \\
\hline NOAER & no dust & no dust & no dust \\
\hline REF & reference experiment & Tegen climatology & Tegen climatology \\
\hline SW & SW dust-radiation interaction & interactive dust & Tegen climatology \\
& only & & interactive dust \\
\hline LW & $\begin{array}{l}\text { LW dust-radiation interaction } \\
\text { only }\end{array}$ & Tegen climatology & interactive dust \\
\hline TOTAL & dust-radiation interaction & interactive dust & Tegen climatology \\
\hline REF_ASSIM & $\begin{array}{l}\text { reference experiment, initial } \\
\text { conditions from assimilation }\end{array}$ & Tegen climatology & interactive dust \\
\hline TOTAL_ASSIM & $\begin{array}{l}\text { dust-radiation interaction, ini- } \\
\text { tial conditions from assimila- } \\
\text { tion }\end{array}$ & interactive dust & \\
\hline
\end{tabular}

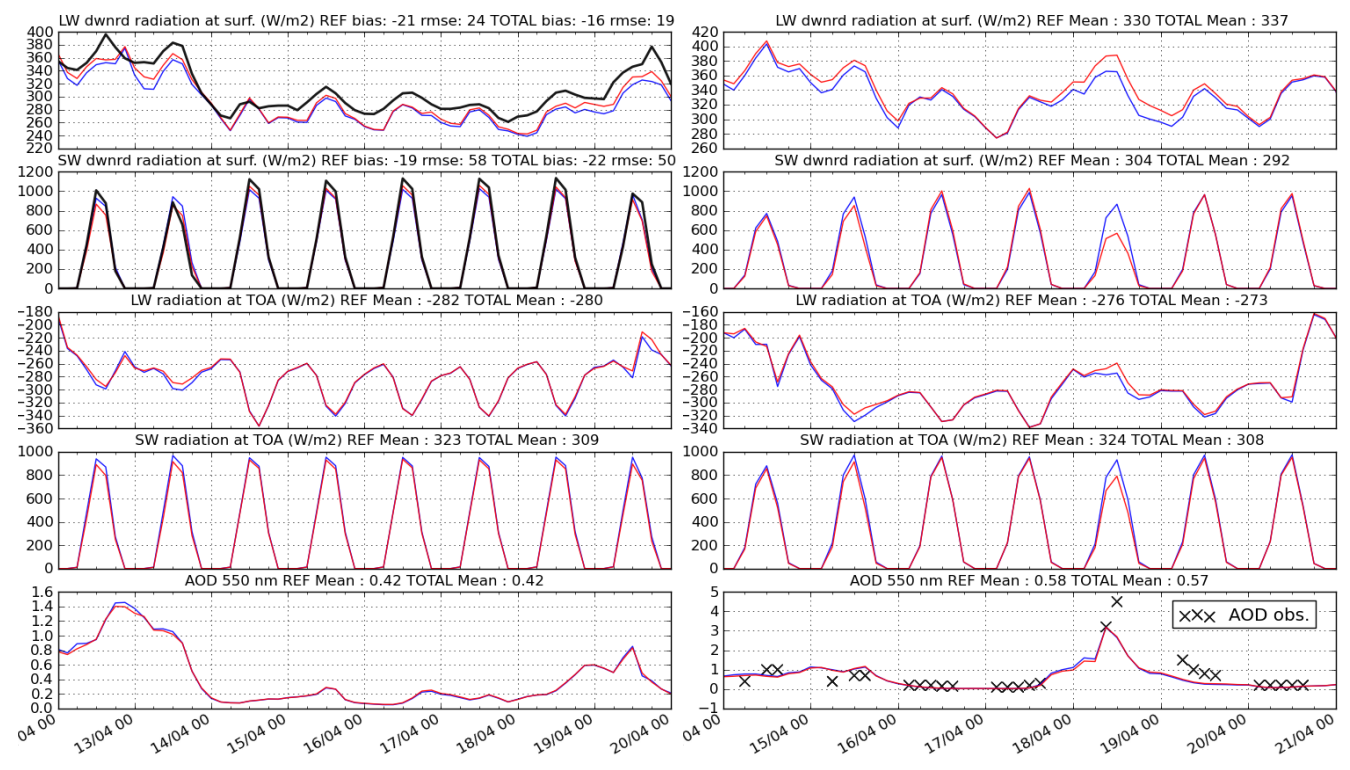

Figure 5. Depicted are 3-24 h forecasts and observations (when available, in black) of downward short-wave and long-wave radiation fluxes at the surface and $550 \mathrm{~nm}$ AOD at Tamanrasset (left) and Cairo (right). REF experiment is in blue, TOTAL is in red and observations are in black. The bias and root-mean-square error (RMSE) of forecasts for observations for the whole period are also indicated on top. By convention, fluxes from the surface are negative and fluxes towards the surface are positive.

was larger then, as shown by Fig. 4 . It exceeded $50 \mathrm{~W} \mathrm{~m}^{-2}$ at the surface, where the dust load was highest. At TOA, the forcings were smaller and lay in the $10-30 \mathrm{~W} \mathrm{~m}^{-2}$ range above the dust storm. These values are close to values found by Haywood et al. (2005) when using the Fouquart et al. (1987) refractive index, and to values found in Perez et al. (2006), Han et al. (2013) and Jish Prakash et al. (2015).

The difference between radiative forcing at the surface and at TOA defines the net atmospheric forcing (Perez et al., 2006); it reached $200 \mathrm{~W} \mathrm{~m}^{-2}$ in the shortwave during the day, and between -15 and $-40 \mathrm{~W} \mathrm{~m}^{-2}$ in the longwave. This means that the radiative forcing in the shortwave provoked a heating of the atmospheric column above the surface, while the forcing in the longwave provoked a smaller cooling of the atmospheric column. These values are consistent with the case studies of Perez et al. (2006) and Miller et al. (2004).

Radiative efficiency is defined as the aerosol radiative effect per unit aerosol optical depth (e.g. Helmert et al., 2007). Figure 7 shows the radiative efficiency corresponding to the radiative forcings shown by Fig. 6 . They ranged from -100 

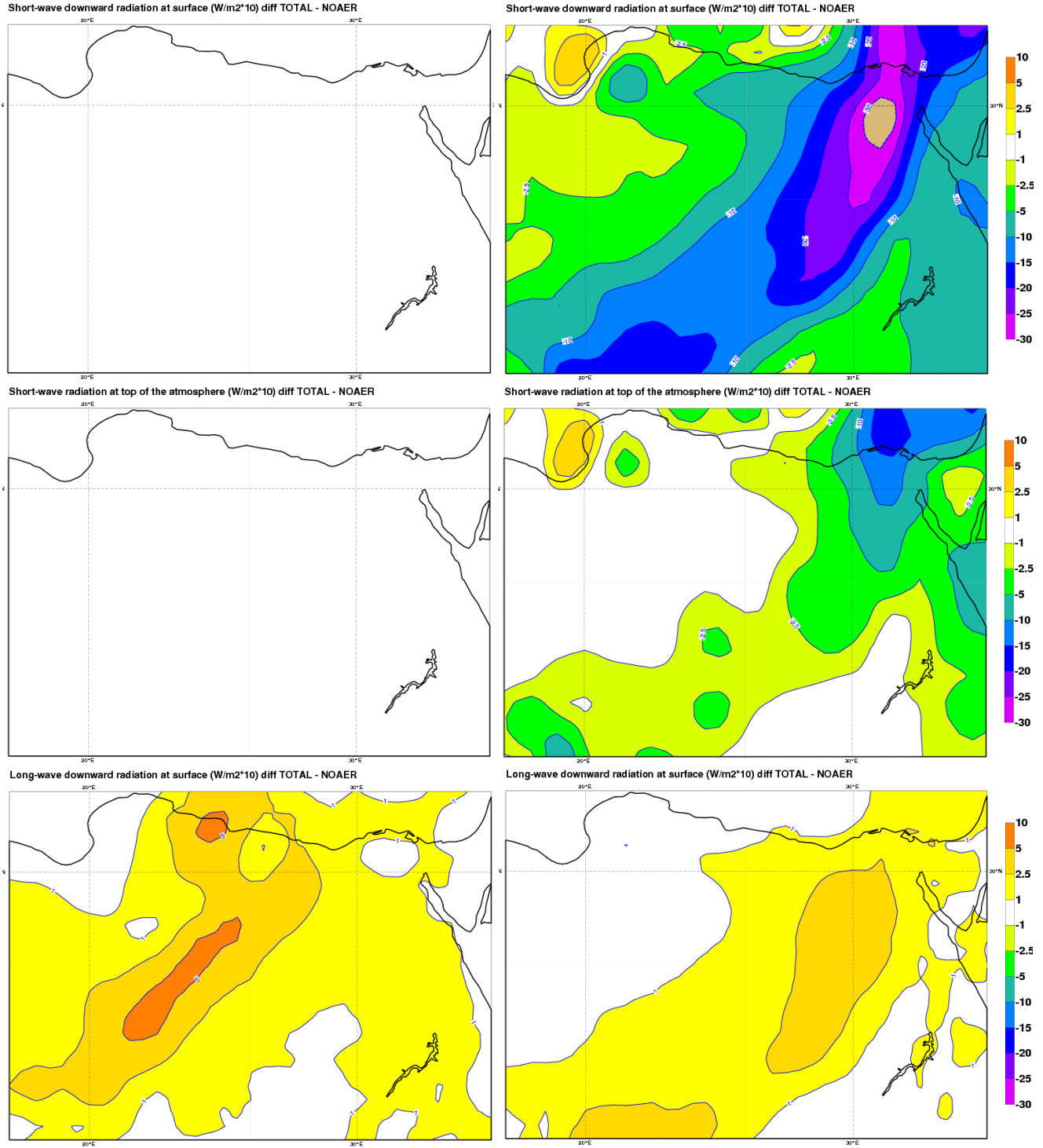

Long-wave downward radiation at surface (W/m2*10) diff TOTAL - NOAER
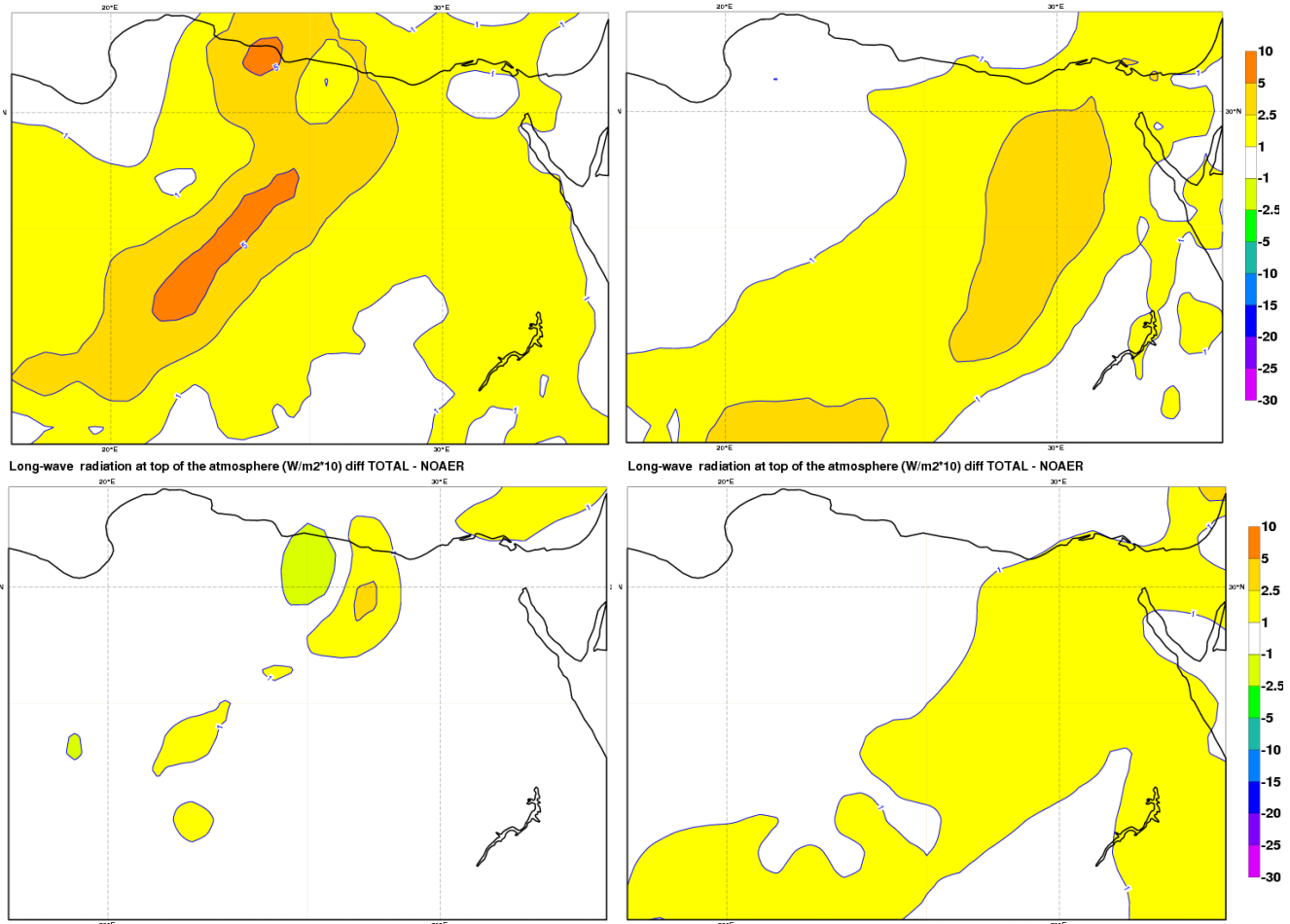

Long-wave radiation at top of the atmosphere (W/m2*10) diff TOTAL - NOAER

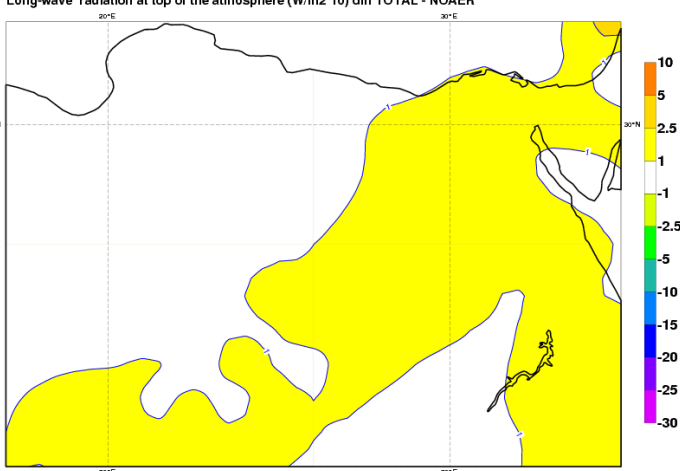

Figure 6. Simulations starting on 17 April 2012, 24 h forecast (left) and $36 \mathrm{~h}$ (right) forecast time. TOTAL-NOAER difference for short-wave radiation fluxes at the surface (top) and TOA (middle top), for long-wave radiation fluxes at the surface (middle bottom) and TOA (bottom). By convention, fluxes from the surface are negative and fluxes towards the surface are positive. 


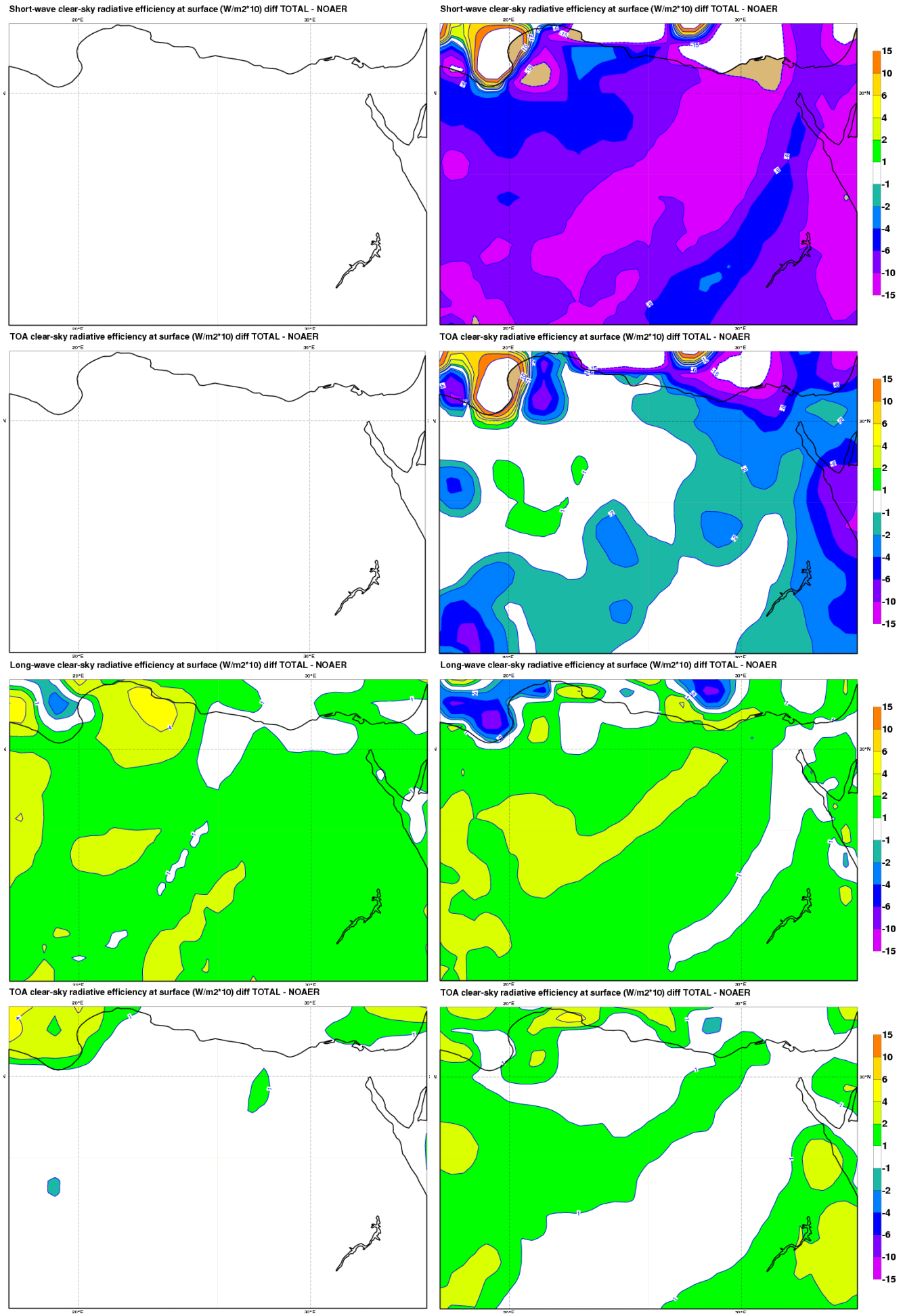

Figure 7. Simulations starting on 17 April 2012, $24 \mathrm{~h}$ forecast (left) and $36 \mathrm{~h}$ (right) forecast time. TOTAL experiment, clear-sky radiative efficiency (defined as the aerosol radiative effect per unit aerosol optical depth) for short-wave radiation fluxes at the surface (top) and TOA (middle top), for long-wave radiation fluxes at the surface (middle bottom) and TOA (bottom). 
to $-150 \mathrm{~W} \mathrm{~m}^{-2}$, with minima of $-200 \mathrm{~W} \mathrm{~m}^{-2}$ in the shortwave at the surface, which is close to the results shown in Helmert et al. (2007) and Stanelle et al. (2010). At TOA, the short-wave radiative efficiency was -20 to $-50 \mathrm{~W} \mathrm{~m}^{-2}$, with a very localized minimum of around $-170 \mathrm{~W} \mathrm{~m}^{-2} \mathrm{~N}$ of the Nile Delta over the Mediterranean Sea. These results are close to Helmert et al. (2007) but contradict those of Stanelle et al. (2010) who find mostly positive values. The very low values over the sea can be explained by the lower surface albedo: Liao and Seinfeld (1998) and Stanelle et al. (2010) showed a clear negative correlation between surface albedo and aerosol radiative forcing. The difference between our results and the results of Stanelle et al. (2010) for short-wave radiative efficiency at TOA could be explained by a difference in the surface albedo over the desert. Our results are also in broad agreement with the regional averages compiled in Yu et al. (2006), once the long-wave component is also taken into account.

The radiative efficiency of dust in the longwave is much smaller as compared to the shortwave. At surface, it ranges from 10 to $30 \mathrm{~W} \mathrm{~m}^{-2}$ in the dust storm. Higher values behind the storm, reaching $50 \mathrm{~W} \mathrm{~m}^{-2}$ in Cyrenaica, are probably artifacts provoked by the low values of AOD there at this time. At TOA, the radiative efficiency lies in the range of 5 to $20 \mathrm{~W} \mathrm{~m}^{-2}$. The regions with highest AOD are collocated with the largest long-wave radiative forcing (see Fig. 6); however the efficiency is lower there. This matches the results shown in Fig. 9 of Stanelle et al. (2010): the link between AOD and long-wave radiative forcing at the surface is not a linear one but rather a logarithmic one (for surface). At TOA, the relationship between AOD and long-wave radiative forcing is weak.

\section{Impact of the dust-short-wave radiation interaction on boundary layer meteorological processes}

In this section, the impact of the solar aerosol-radiation interaction on meteorological parameters and dust production is investigated. Figure 8 shows observed (when available) and forecasted meteorological parameters, dust production flux and $550 \mathrm{~nm}$ AOD at Cairo and at the Siwa Oasis, which lies at $29^{\circ} 12^{\prime} \mathrm{N}, 25^{\circ} 29^{\prime} \mathrm{E}$, for the REF and the SW experiments. The latter location was chosen because it was affected by the dust storm from the morning of 17 April to the afternoon of 18 April, whereas Cairo was mainly affected around midday on 18 April.

The strong radiative forcing in the shortwave (see Fig. 6) had a notable influence on maximum temperatures which are up to $3^{\circ}$ lower for the SW experiment on 18 April at Cairo, and $2-3^{\circ}$ lower on 17 April at Siwa. This increased a small negative bias, from $-0.1 \mathrm{~K}$ for REF to $-0.4 \mathrm{~K}$ for $\mathrm{SW}$ at Cairo, and from -0.8 to $-1 \mathrm{~K}$ at Siwa. As the surface is less hot during the day with SW, the sensible heat flux also decreased by up to $150 \mathrm{~W} \mathrm{~m}^{-2}$ on 18 April 2012 at Cairo and up to $50 \mathrm{~W} \mathrm{~m}^{-2}$ at Siwa on 17 April. The impact was smaller at Siwa because of the timing of the dust storm which occurred during the night of 17-18 April.

Lower maximum temperatures and sensible heat flux increased the stability of boundary layer (BL), similarly to the process described in Perez et al. (2006) and Miller et al. (2004). This provoked a decrease of wind speed at $10 \mathrm{~m}$ during daytime, by up to 1 to $1.5 \mathrm{~m} \mathrm{~s}^{-1}$ on 17 April at Siwa and on 18 April at Cairo, with little impact on scores.

Dust production was smaller with SW because of lower wind speed at the surface, by $25 \%$ lower at midday on 18 April at Cairo, and $15-25 \%$ on the second half of 17 April and also at midday on 14 April at Siwa. Dust production was around 30 times larger at Siwa than at Cairo during the storm, because of higher sustained winds so that the absolute impact on dust production was much larger for Siwa: the difference between REF and SW was around 20 times larger at Siwa than at Cairo. This also shows that the dust layer was mainly advected at Cairo, while it was both advected and produced at Siwa.

Lower dust emissions brought an overall decrease of AOD with SW. The impact was rather small at Cairo, which was farther from dust sources than at Siwa; dust AOD was on average 0.03 lower for SW, and up to $0.2-0.3$ lower on the morning of 18 April. At Siwa, closer to the main dust emitting regions, dust AOD was lower by 0.05 on average, and by more than 0.5 on the afternoon and evening of 17 April. A bit further to the north-west, closer to the heart of the dust storm, the AOD difference reached nearly 1 . Changes in wind speed can be caused by a combination of the following factors.

- Synoptic causes: the pressure gradient changes the surface geostrophic wind.

- Dynamic thermal causes: the horizontal temperature gradient impacts the change in geostrophic wind with height.

- Vertical stability causes: a different thermal stratification of the boundary layer modifies the vertical structure of the winds in the boundary layer.

The horizontal gradient of surface pressure affects surface geostrophic wind via the geostrophic wind equation (Holton, 2004):

$\boldsymbol{U}_{g}(0)=\frac{\boldsymbol{k}}{f \rho} \times \nabla_{z} p(0)$.

The horizontal gradient of temperature affects the vertical gradient of geostrophic wind via the thermal wind equation (Holton, 2004):

$\boldsymbol{V}_{\mathrm{T}}=\boldsymbol{U}_{g}(1)-\boldsymbol{U}_{g}(0)=\frac{R}{f} \ln \left[\frac{p_{0}}{p_{1}}\right] \boldsymbol{k} \times \nabla_{p} \bar{T}$.

$V_{\mathrm{T}}$ is the so-called "thermal wind", the difference between geostrophic wind at altitudes (0) and (1). $R$ is the specific gas 

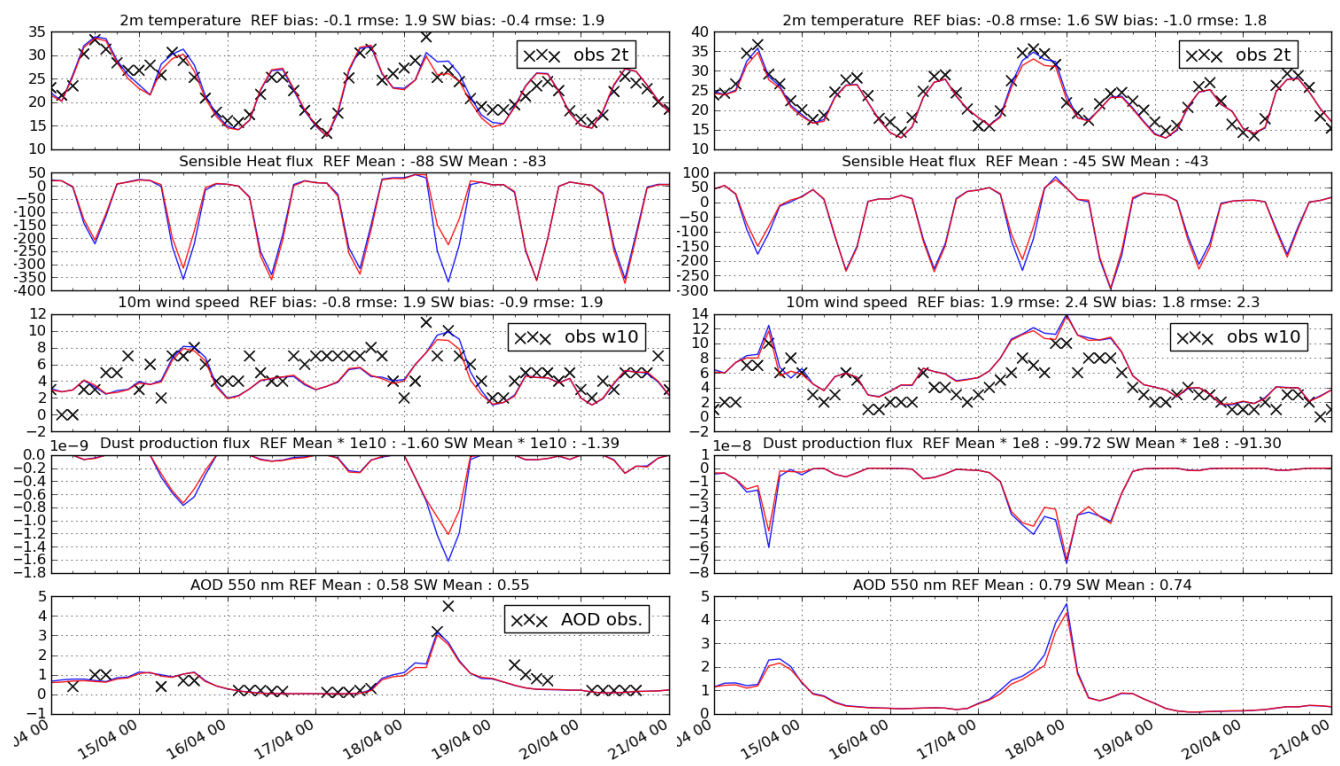

Figure 8. REF (blue) vs. SW (red) experiment, 3 to $24 \mathrm{~h}$ forecasts and observations of $2 \mathrm{~m}$ temperature (in ${ }^{\circ} \mathrm{C}$ ), sensible heat flux (in $\mathrm{W} \mathrm{m}^{-2}$ ), $10 \mathrm{~m}$ wind speed (in $\mathrm{m} \mathrm{s}^{-1}$ ), dust production flux (in $\mathrm{kg} \mathrm{m}^{-2} \mathrm{~s}^{-1}$ ) and AOD at $550 \mathrm{~nm}$. Figures at Cairo are on the left panel and at Siwa Oasis on the right. For heat flux, negative values indicate that the surface warms the atmosphere.

constant for air, $f$ is the Coriolis parameter, $k$ is the vertical unit vector, $\rho$ is the air density, $(0)$ denotes the surface and (1) a specific height above. The subscript $p$ on the gradient operator denotes a gradient on a constant pressure surface, and the subscript $z$ a gradient on a constant altitude surface.

The thermal stratification of the boundary layer affects winds at the surface via a modification of the turbulent momentum exchange coefficients, which are calculated in the MACC-II system using the Monin Obukhov similarity theory (more details can be found at https://software.ecmwf.int/ wiki/display/IFS/CY40R1+Official+IFS+Documentation).

A decrease of the vertical gradient of temperature is associated with a decrease in sensible heat flux at the surface (see Fig. 8) and, as described in detail in Perez et al. (2006), by a decrease in surface turbulent heat and momentum exchanges, and thus in lower wind speed at the surface.

To better understand the interaction between dust and meteorology and to help distinguish between the different causes for the changes in wind speeds brought by SW, Fig. 9 shows the difference between SW and REF for a set of meteorological parameters, for a $36 \mathrm{~h}$ forecast starting on 17 April 2012, 00:00 UTC, close to the local solar maximum. The region with lower $2 \mathrm{~m}$ temperature was nicely collocated with the region with high AODs (as shown on Fig. 4). Temperature at $850 \mathrm{hPa}$ was also generally lower for SW as compared to REF, but by a smaller margin as compared to $2 \mathrm{~m}$ temperature: $0.5-1.5 \mathrm{~K}$ against $1-3 \mathrm{~K}$ at $2 \mathrm{~m}$ for regions with AOD above 1 . This differential impact of surface and $850 \mathrm{hPa}$ temperature affected the thermal stratification of the planetary boundary layer (PBL) and was one cause for generally lower wind speed at $10 \mathrm{~m}$. A band of higher surface wind speed and dust production lay at the west of Lake Nasser, showing that the modification of the thermal stratification of the atmosphere was not the only phenomenon that impacted winds and dust production.

Figure 9 also shows the difference between SW and REF for mean sea-level pressure and wind speeds at $925 \mathrm{hPa}$. Wind speeds at $925 \mathrm{hPa}$ are less influenced by surface properties and should be more representative of the large-scale component of wind speed. They difference between REF and LW was smaller for $925 \mathrm{hPa}$ winds than for surface winds. This suggests that the synoptic factors brought a smaller contribution than other factors to the decrease of surface winds with SW. Surface pressure was everywhere higher with SW, by 0.2 to $1 \mathrm{hPa}$ in general. The distribution of the differences is quite uniform except just in front of the storm; it is well collocated with the area where $2 \mathrm{~m}$ temperature is significantly lower with SW. As a consequence, surface geostrophic wind, a good measure of the synoptic component of wind, generally did not differ much between SW and REF except locally at the edge of the storm.

Figures 4 and 9 show that the area where surface wind speed was higher for SW corresponds to an area of important horizontal thermal gradient associated with the cold front that was causing the dust storm. From east to west, $2 \mathrm{~m}$ temperature decreased by more than $10 \mathrm{~K}$ in no more than a few hundred kilometres along the $22^{\circ} \mathrm{N}$ parallel. The western part of this high gradient area was heavily impacted by the reduced incoming solar radiation: $2 \mathrm{~m}$ temperature there was up to $2 \mathrm{~K}$ lower with SW. The eastern part lay in front of the dust storm and was not yet affected: the dust load there was not very high and temperatures were reduced by only 0.5 to $1 \mathrm{~K}$. 

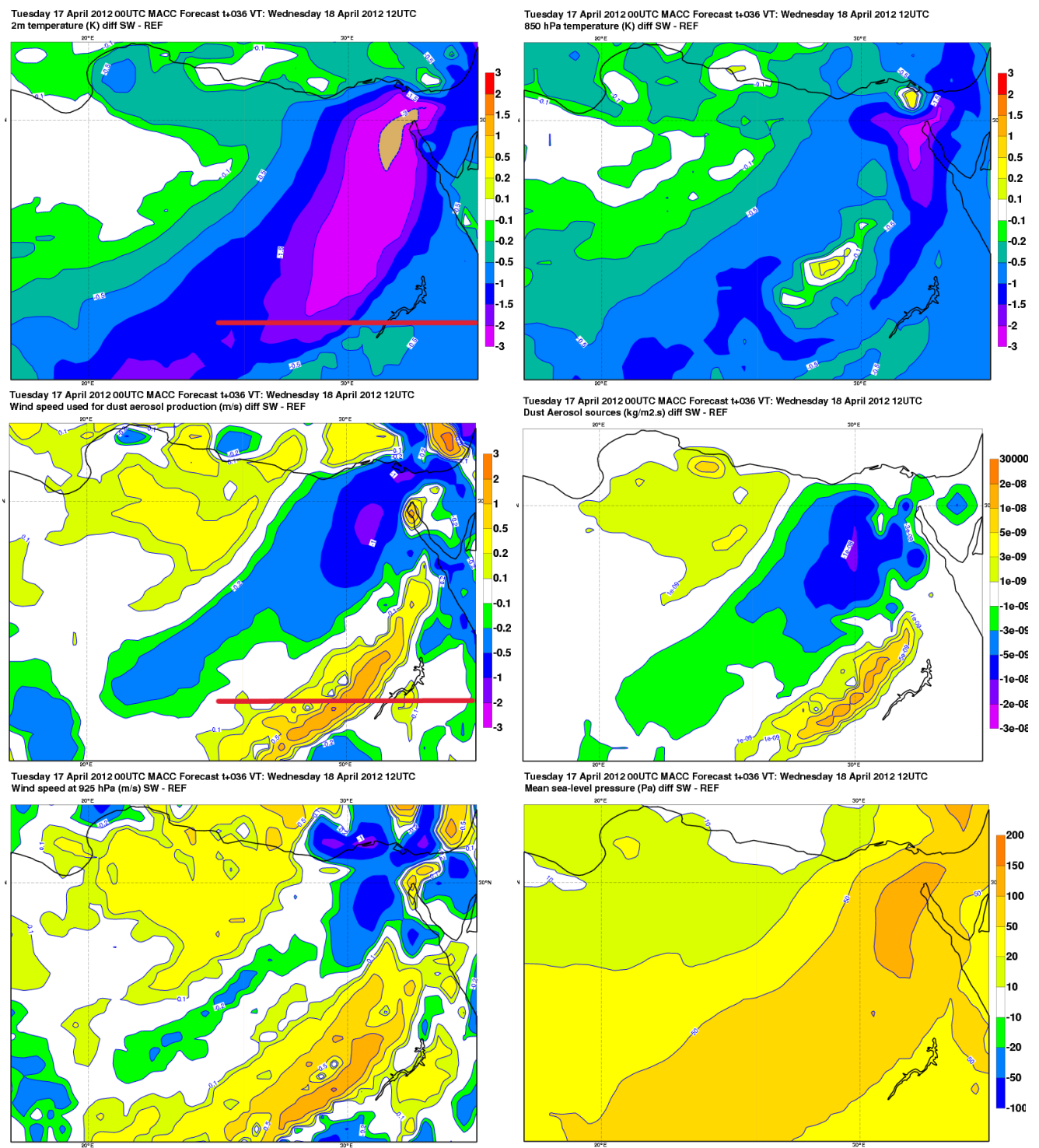

Figure 9. Simulations starting on 17 April 2012, $36 \mathrm{~h}$ forecast. Difference of SW-REF for $2 \mathrm{~m}$ temperature (top left), $850 \mathrm{hPa}$ temperature (top right), $10 \mathrm{~m}$ wind speed (middle left), dust production (middle right), wind at $925 \mathrm{hPa}$ (bottom left), sea-level pressure (bottom right). The red line on the $10 \mathrm{~m}$ wind speed and $2 \mathrm{~m}$ temperature panels indicate the cross section of Fig. 9.

The differential impact of the dust layer on $2 \mathrm{~m}$ temperature thus increased the horizontal gradient in this region by more than $1 \mathrm{~K}$

This is confirmed by Fig. 10, which presents a cross section of surface pressure, temperature and wind speed along the $22^{\circ} \mathrm{N}$ parallel. The horizontal pressure gradient between $29^{\circ}$ and $30^{\circ} \mathrm{E}$ was slightly larger for SW than for REF: $2 \mathrm{hPa} / 100 \mathrm{~km}$ against $1.7 \mathrm{hPa} / 100 \mathrm{~km}$; this brought an increase in surface geostrophic wind of about $1.5 \mathrm{~m} \mathrm{~s}^{-1}$, which is not enough to explain the increase in $10 \mathrm{~m}$ wind speed at the same place, of more than $2 \mathrm{~m} \mathrm{~s}^{-1}$ at the surface and $3 \mathrm{~m} \mathrm{~s}^{-1}$ at $925 \mathrm{hPa}$. Between 29 and $30^{\circ} \mathrm{E}$, the horizontal thermal gradient was $5 \mathrm{~K} / 100 \mathrm{~km}$ for REF, against more than
$6 \mathrm{~K} / 100 \mathrm{~km}$ for $\mathrm{SW}$. At $925 \mathrm{hPa}$, it reached $5 \mathrm{~K} / 100 \mathrm{~km}$ for $\mathrm{REF}$, against $4 \mathrm{~K} / 100 \mathrm{~km}$ for $\mathrm{SW}$. This translates into an increase of geostrophic wind between the surface and $925 \mathrm{hPa}$ of more than $2 \mathrm{~m} \mathrm{~s}^{-1}$ between REF and SW at this location. Winds at the surface, 925 and $850 \mathrm{hPa}$ (not shown) in this region, are all between 2 and $4 \mathrm{~m} \mathrm{~s}^{-1}$ stronger with SW. This is in contrast with the general decrease of winds associated with the changes in thermal stratification, which concerns only the surface and not higher regions.

To sum up, the aerosol-radiation interaction in the shortwave is at the origin of two feedbacks between aerosol and meteorology: a negative one that is driven by the differential changes between temperature at the surface and at the top of 

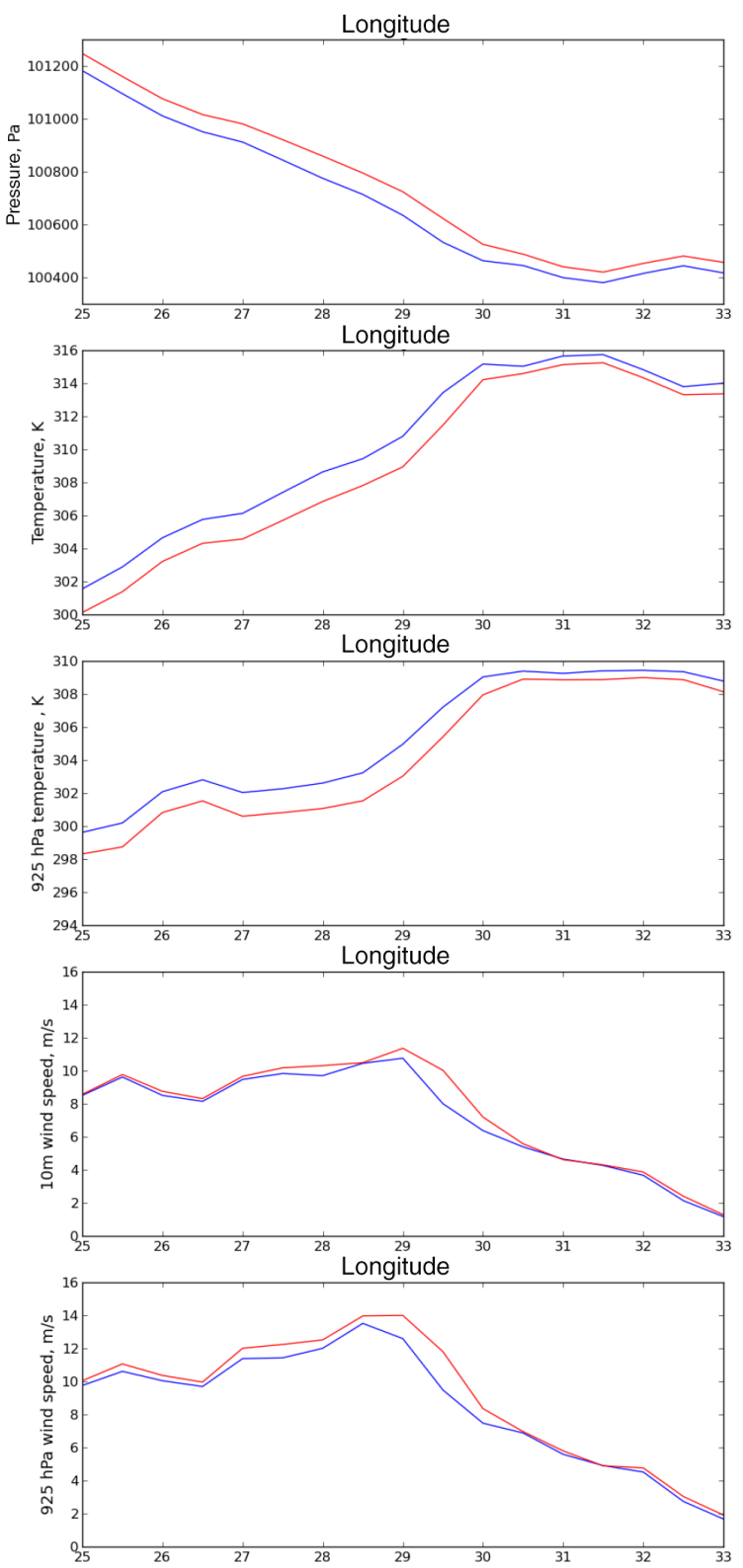

Figure 10. Simulations starting on 17 April 2012, 36h forecast, cross section at $22^{\circ} \mathrm{N}$. Mean sea-level pressure (top), $2 \mathrm{~m}$ temperature (middle top), $925 \mathrm{hPa}$ temperature (middle), $10 \mathrm{~m}$ wind speed (middle bottom) and $925 \mathrm{hPa}$ wind speed (bottom) for REF (blue) and SW (red).

the PBL, which in turn increases thermal stability of the PBL, and decreases surface winds and dust production. This feedback was documented by Perez et al. (2006) and Miller et al. (2004). A local positive feedback occurs at the edge of the dust layer, where during daytime the horizontal temperature gradient was locally increased by the differential impact of the dust layer on surface temperatures. This increase in horizontal gradient in turn locally increased geostrophic wind to $925 \mathrm{hPa}$ and higher, as well as surface wind, and thus dust production. This local feedback may also be the cause of the local increase in wind speed noted at the edge of a large dust plume in Fig. 6b of Ahn et al. (2007).

Surface winds are marginally impacted by changes in surface geostrophic winds brought by surface pressure changes. They are widely decreased by changes in the thermal stratification, as already noted by Perez et al. (2006). They are locally increased by changes in geostrophic winds above the surface caused by differences in the horizontal temperature gradient. As Fig. 15 shows, the overall difference SW-REF for dust AOD was negative, which means that the negative feedback driven by vertical stratification factors is predominant compared to the local positive feedback driven by the "thermal wind".

\section{Impact of the dust-long-wave radiation interaction on boundary layer meteorological processes}

In this section, the impact of the thermal aerosol-radiation interaction on meteorological parameters and dust production is investigated. Figure 11 shows observed (when available) and forecasted meteorological parameters, dust production flux and $550 \mathrm{~nm}$ AOD at Cairo and at the Siwa Oasis for the REF and the LW experiments.

The level of $2 \mathrm{~m}$ temperature was higher during the nights with the LW experiment, because the dust aerosol layer emits downwards in the longwave and increases downward longwave radiation (cf. Figs. 5 and 6). With high dust load, the difference reached up to $1.5 \mathrm{~K}$ for Cairo, and up to $2 \mathrm{~K}$ for Siwa. This helped to reduce a cold bias for night-time temperatures at Siwa, from -0.8 to $0.4 \mathrm{~K}$ over the considered period. At Cairo, the daytime temperature on 18 April was also significantly higher with $\mathrm{LW}$, by 0.5 to $1 \mathrm{~K}$. This translated into slightly larger sensible heat fluxes, by about $30 \mathrm{~W} \mathrm{~m}^{-2}$. At Siwa, night-time cooling on the night of 17/18 April was significantly reduced and even partially reversed. At the beginning of that night, the heat fluxes indicate a cooling surface for REF and a warming one for LW.

The impact on surface wind speed was small at both Cairo and Siwa. Dust production, however, which follows a cubic function of surface wind, was significantly larger with LW, by up to $15 \%$ at midday on 18 April at Cairo, and by up to $20 \%$ in the evening of 17 April at Siwa. AOD was only marginally affected at Cairo, which is farther from the main dust emitting regions; the difference was significant at Siwa, where AOD maximum during the night of 17-18 April was increased by nearly 0.5 . Figures 15 and 4 show that on the night of 17-18 April, the area where AOD was larger by more than 0.3 with LW was extensive and well collocated with the area with high dust load and larger downward longwave fluxes at the surface.

Figure 12 shows the difference on 18 April, 00:00 UTC, between LW and REF for a set of meteorological parameters as well as dust production. The level of $2 \mathrm{~m}$ temperature was 

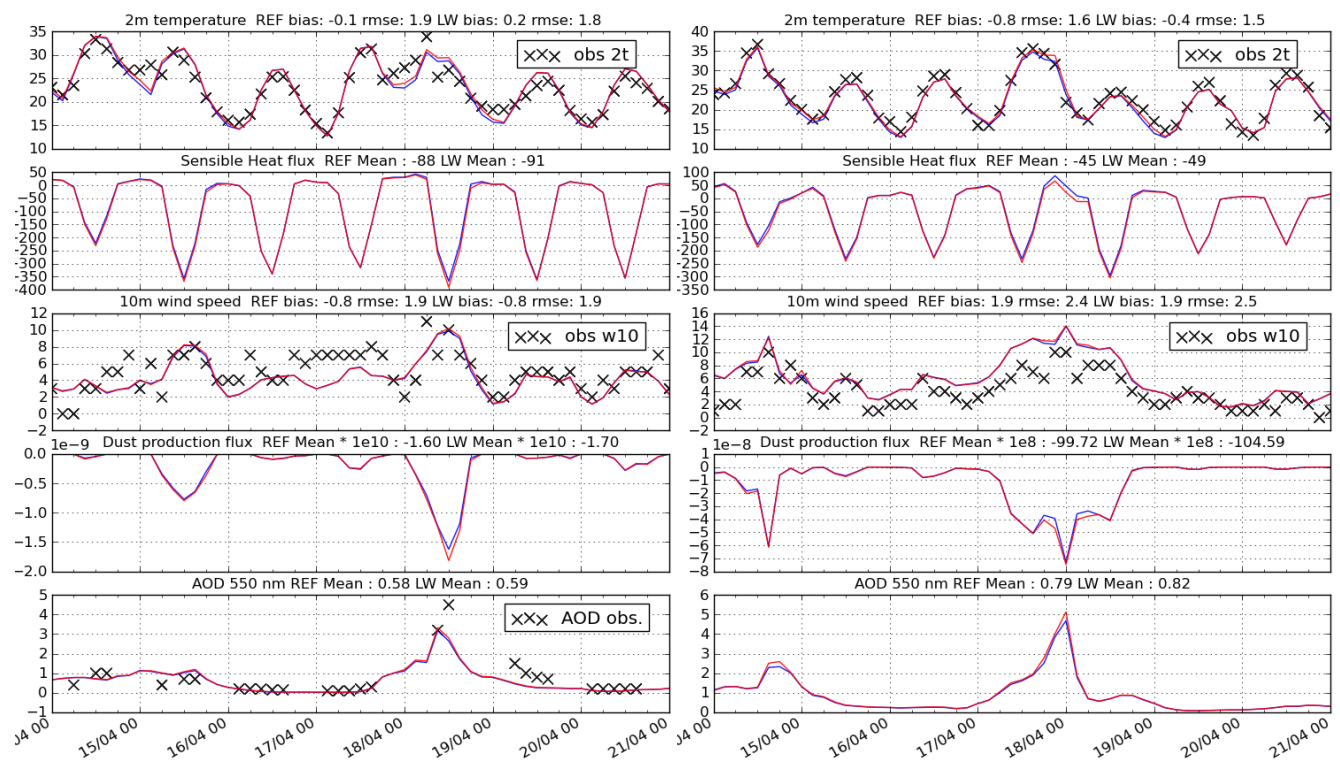

Figure 11. Same as Fig. 8 for REF (blue) vs. LW (red) experiments.

larger for LW over most continental surfaces, by 0.3 to $0.5 \mathrm{~K}$ in regions where the dust load was not very important, and by 1 to $2.5 \mathrm{~K}$ in regions where dust AOD exceeded 2. This difference was caused by emission in the thermal spectrum by the dust layer, which lies mostly below $850 \mathrm{hPa}$. Temperatures at $850 \mathrm{hPa}$ were affected in a different measure: over most areas they were slightly lower for LW. Over a band that corresponds to the cold front, $850 \mathrm{hPa}$ temperature was higher by $0.2-0.5 \mathrm{~K}$. This different impact of long-wave aerosolradiation interaction between surface and $850 \mathrm{hPa}$ affected the stability of the PBL strongly.

A less stable boundary layer with LW was associated with slightly stronger winds at the surface, by $0.3-1 \mathrm{~m} \mathrm{~s}^{-1}$ over most areas. The area of higher $850 \mathrm{hPa}$ temperatures with $\mathrm{LW}$ was associated with weaker surface winds, by 0.5 to $1 \mathrm{~m} \mathrm{~s}^{-1}$. At $925 \mathrm{hPa}$, the pattern of wind change was more complex, with a marked dipole pattern, which suggests that the speed of cold front was increased by the LW experiment. This could also explain the dipole in $850 \mathrm{hPa}$ temperatures. Generally higher temperatures at the surface were associated with lower surface pressure, by 0.5 to $1 \mathrm{hPa}$. As the decrease in pressure happened behind the cold front, in a region where pressure is building up after the front, this resulted in a slight reduction in the pressure gradient and thus surface geostrophic winds (not shown) behind the cold front. The synoptic impact of aerosols-long-wave radiation on wind speed was thus negative for this situation, but it was generally small in intensity, except at the edges of the dust storm, where the pressure gradient was notably increased. This is clear in the differences in wind speed at $925 \mathrm{hPa}$, which shows a band of positive values that is exactly collocated with the edge of the zone where surface pressure is different between REF and LW.
The widespread increase in surface winds translated into mostly larger dust emissions. The notable exception was the area with lower surface wind speeds that lies just before the cold front. As a consequence, dust AOD was generally larger for LW (see Fig. 15); values were however significantly lower just before the cold front.

As done for the SW aerosol forcing, to better understand the phenomena taking place around the cold front, Fig. 13 presents a cross section of various meteorological parameters along the $22^{\circ} \mathrm{N}$ parallel. The pressure gradient along $22^{\circ} \mathrm{N}$ was modified by LW, the difference in pressure gradient reaching $0.3 \mathrm{hPa} / 100 \mathrm{~km}$ between 22 and $23^{\circ} \mathrm{E}$. This difference translates into a surface geostrophic wind that is around $1.5 \mathrm{~m} \mathrm{~s}^{-1}$ lower (Eq. 1) at this location with LW. The level of $2 \mathrm{~m}$ temperature gradient was not very different between $\mathrm{REF}$ and LW; at $925 \mathrm{hPa}$, the radiative impact of aerosols in the longwave had a more differentiated effect on temperatures: the temperature gradient between 22 and $23^{\circ} \mathrm{E}$ was smaller by $1 \mathrm{~K} / 100 \mathrm{~km}$ with $\mathrm{LW}$. This reduced the "thermal wind", i.e. the difference between geostrophic wind at the surface and at $925 \mathrm{hPa}$ by around $1.5 \mathrm{~m} \mathrm{~s}^{-1}$ with LW (Eq. 2). The impact of the decrease of surface geostrophic wind between 22 and $23^{\circ} \mathrm{E}$ is clear on $10 \mathrm{~m}$ winds, which were significantly lower there, and on winds at $925 \mathrm{hPa}$, which were also lower in this region with LW and very similar elsewhere in the cross section.

To sum up, the aerosol-radiation interaction in the longwave is at the origin of two feedbacks between aerosol and meteorology: a positive one that is driven by the differential changes between temperature at the surface and at the top of the PBL, which in turn decreases the thermal stability of the PBL and increases surface winds and dust production. This mechanism is the symmetrical opposite of the one described 

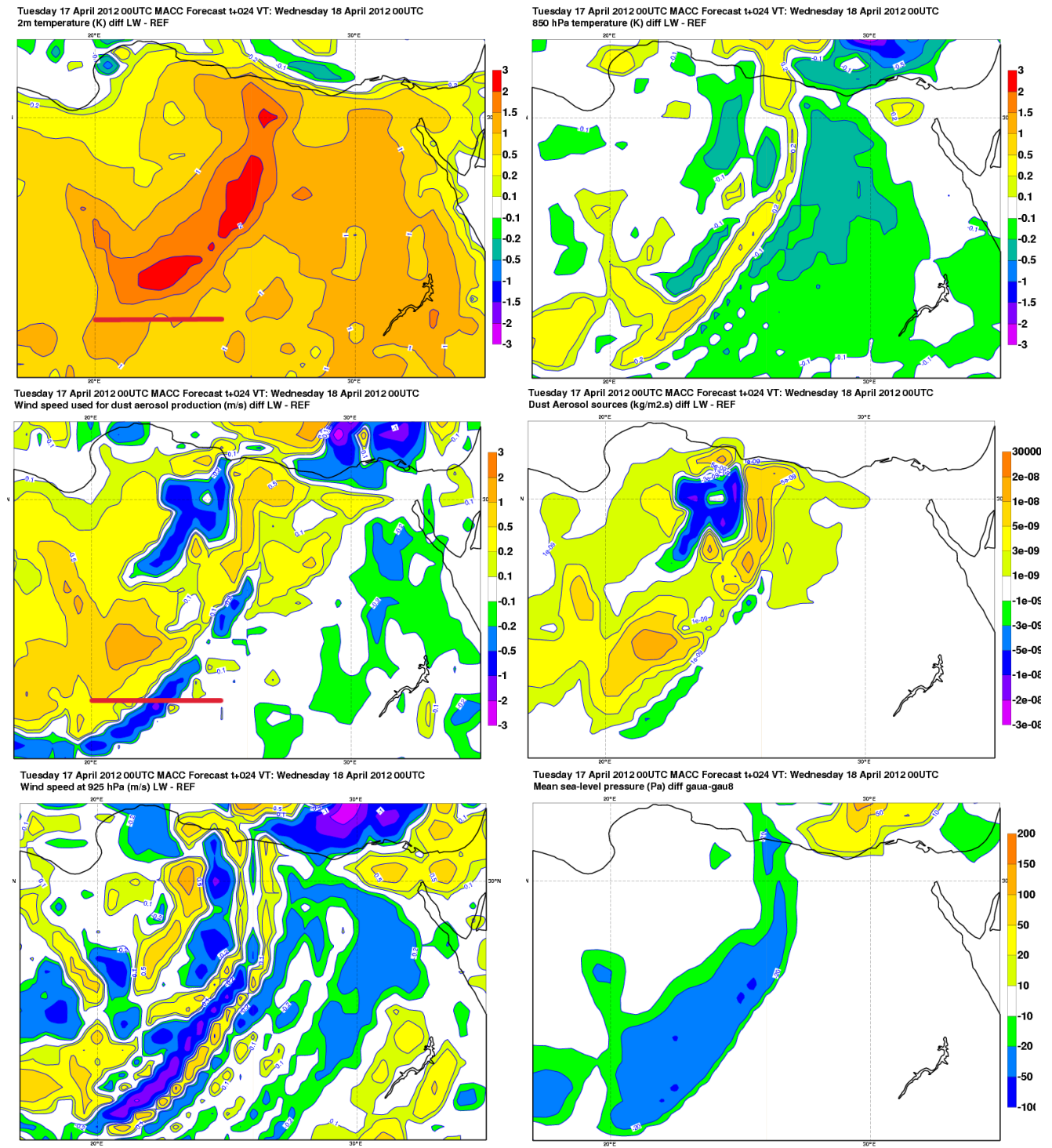

Figure 12. Simulations starting on 17 April 2012, $24 \mathrm{~h}$ forecast. Difference of LW-REF for $2 \mathrm{~m}$ temperature (top left), $850 \mathrm{hPa}$ temperature (top right), $10 \mathrm{~m}$ wind speed (middle left), dust production (middle right), wind at $925 \mathrm{hPa}$ (bottom left) and sea-level pressure (bottom right). The red line on the $10 \mathrm{~m}$ wind speed and $2 \mathrm{~m}$ temperature panels indicates the cross section of Fig. 13.

for the SW experiment and by Perez et al. (2006). A local negative feedback occurs at the edge of the dust layer, where during night-time the horizontal temperature gradient is locally decreased by the differential impact of the dust layer on temperatures at $925 \mathrm{hPa}$, thus decreasing geostrophic wind above the surface. Dust production and AOD are likewise affected, thus enhancing this negative feedback. In contrast with the SW experiments, the surface geostrophic wind is significantly affected by surface pressure changes with LW. This translates into local increases in winds at $925 \mathrm{hPa}$ and above.

\section{Interaction of total aerosol radiative impact}

In this section, the reference experiment is compared against TOTAL, which uses prognostic aerosols to compute aerosolradiation interaction in both SW and LW spectra.

The impact on wind speed was of the same nature as SW and LW for day and night respectively, but reduced in amplitude. As for SW and LW, a positive (respectively negative) feedback developed at the edge of the dust plume, just before the cold front. As these feedbacks are symmetrical between SW and LW, they are strongly reduced when the two are combined. This is why the areas where the change of thermal winds affected winds and dust emission are the same between SW during the day, LW during the night, and TOTAL, 

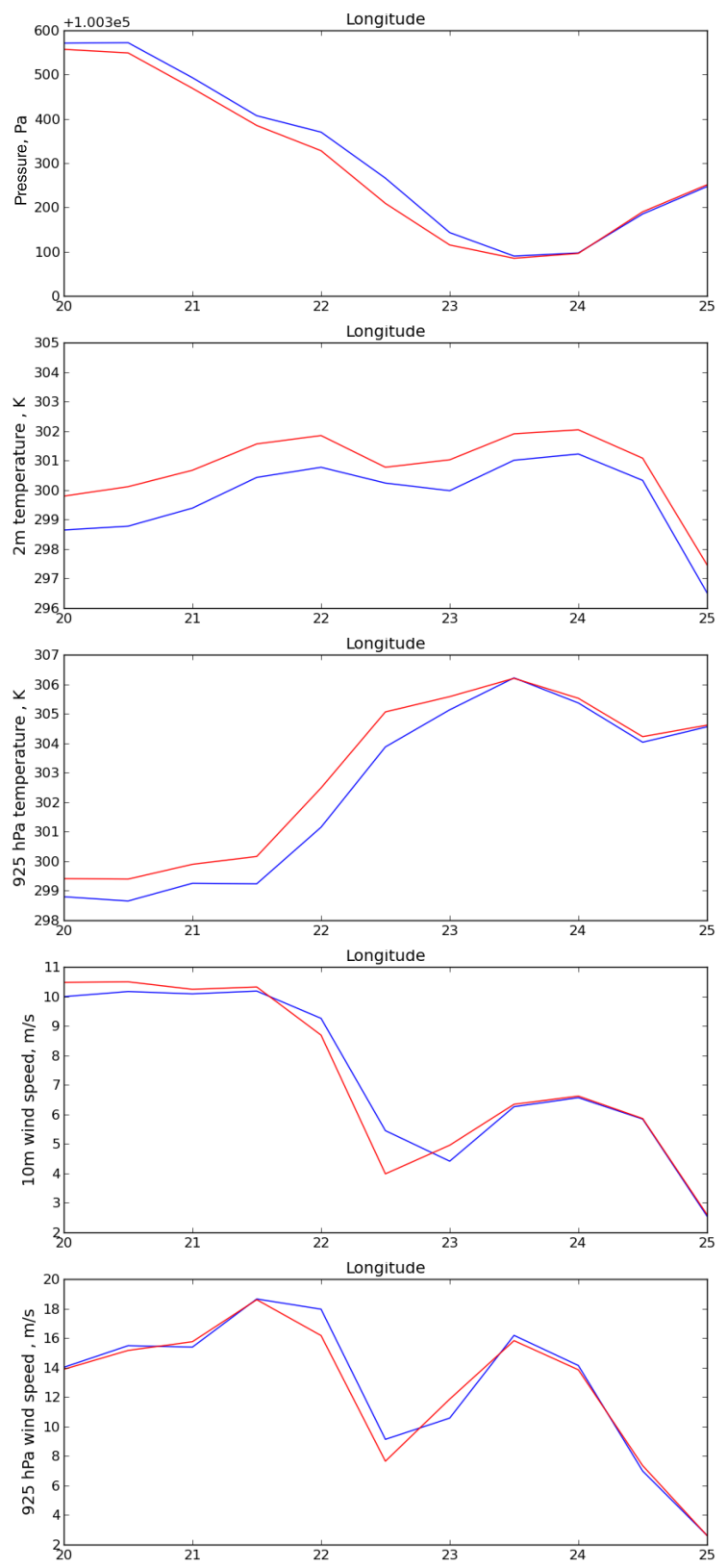

Figure 13. Same as Fig. 10 for REF (blue) and LW (red), cross section at $22^{\circ} \mathrm{N}, 24 \mathrm{~h}$ forecast.

but are much reduced in intensity. These structures have less impact on dust emissions and dust AOD than in the SW and LW experiments. The areas where winds were decreased (by $0.2-0.8 \mathrm{~m} \mathrm{~s}^{-1}$ ) or increased (by $0.5-1 \mathrm{~m} \mathrm{~s}^{-1}$ ) by the changes in thermal stratification of the PBL are however clearly visible; dust emissions reflect the changes in wind speed. The impact of these two conflicting changes appear to be of similar amplitude: total AOD changes were much smaller for TOTAL as compared to SW or LW (see Fig. 15).

Vertical profiles of dust, wind speed and temperature before and after the passage of the cold front are shown in
Fig. 14. Dust is mainly confined to the boundary layer, the top of which lay at around $800 \mathrm{hPa}$ at 15:00 UTC and just above $950 \mathrm{hPa}$ at 03:00 UTC. The impact of the meteorology on dust emissions is again clear on this plot: dust mixing ratio was 20 to 50\% lower with TOTAL at 15:00 UTC, and slightly larger at 03:00 UTC. The impact of aerosols on temperatures was evident: light scattering occurred in the dust layer and reduced temperatures by $1-2 \mathrm{~K}$ below $925 \mathrm{hPa}$ at 15:00 UTC for TOTAL and by a smaller amount, less than $0.5 \mathrm{~K}$, between 800 and $925 \mathrm{hPa}$. At 03:00 UTC, thermal radiation from the dust layer provoked a small increase in temperature for TOTAL very close to the surface, below $970 \mathrm{hPa}$. Above that height, the atmosphere was cooler with TOTAL, because the dust layer absorbed part of the radiation from the surface. Winds for TOTAL were slightly weaker at 15:00 UTC at the surface, and slightly stronger at 03:00 UTC. Above the surface, winds were mostly stronger at 15:00 UTC, by up to nearly $1 \mathrm{~m} \mathrm{~s}^{-1}$ at $750 \mathrm{hPa}$. At $925 \mathrm{hPa}$ with TOTAL, there was a small temperature inversion because the aerosol layer cooled the atmosphere below that height. Associated with this small temperature inversion was a significant increase of wind speed, by around $1 \mathrm{~m} \mathrm{~s}^{-1}$. At 03:00 UTC, winds were stronger just above the top of the PBL, by around $1 \mathrm{~m} \mathrm{~s}^{-1}$.

Clear-sky nights are generally characterized by very stable PBLs over the desert since the heat capacity of sand is small compared to other soil types. This very stable PBL is in turn at the origin of nocturnal low-level jets (NLLJs). NLLJs in north Africa can be formed by different mechanisms; here the driving mechanism is an inertial oscillation (Knippertz, 2008; Van de Wiel et al., 2010), which compensates for the low value of surface winds caused by surface friction and by very high PBL stability by a low-level jet that lies below the top of the PBL, with wind speed above the geostrophic wind values. NLLJs are an important driver for dust emission in north Africa (Fiedler et al., 2013; Heinold et al., 2013, 2015). Heinold et al. (2008) studied the feedback between dust and NLLJs and found that the intensity of NLLJs was locally enhanced by the radiative impact of a dust layer on the shortwave: a more stable boundary layer leads to a more intense NLLJ. This led to locally stronger winds during daytime, during the moment of the breakdown of NLLJs. On the other hand, higher nocturnal surface temperatures under the layer of dust associated with the long-wave effect of dust decreased significantly the PBL stability, which could have a weakening impact on NLLJs. The winds profiles of Fig. 14 at night show a strengthening of the NLLJ with TOTAL, which is consistent with the findings of Heinold et al. (2008). In this situation and for this phenomenon, the impact of dust on solar radiation was predominant over the impact on long-wave radiation.

To sum up, TOTAL is a composition of LW and SW: the mainly positive feedback between dust and meteorology associated with LW and the mainly negative feedback associated with SW co-exist and also impact each other. This com- 

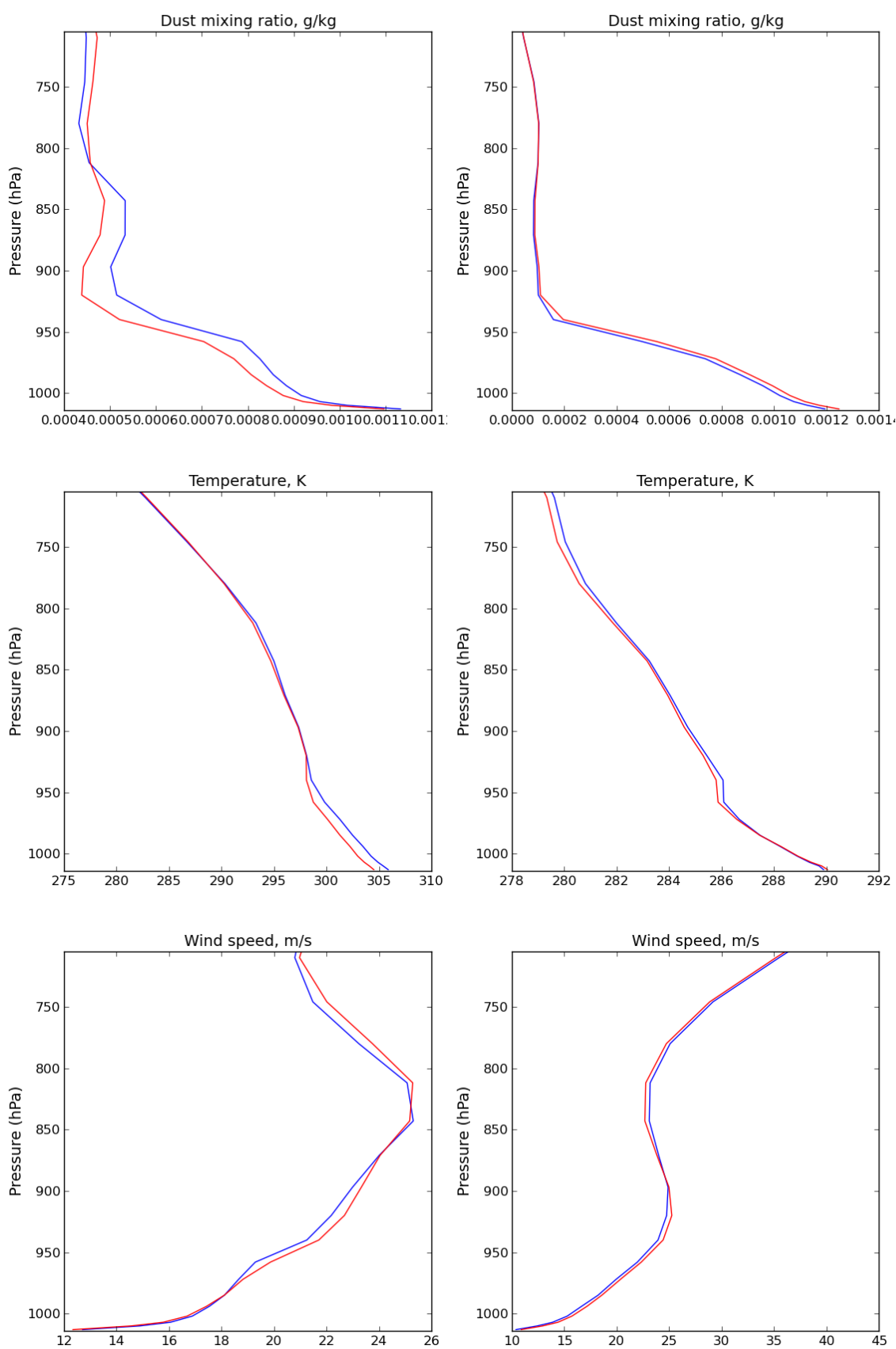

Figure 14. Vertical profile of dust mixing ratio (top), temperature (middle) and wind speed (bottom) at Siwa Oasis. Forecasts starting on 17 April 2012, 00:00 UTC, lead time $15 \mathrm{~h}$ (left) and $27 \mathrm{~h}$ (right). REF is in blue, TOTAL in red.

pletes the mechanism described in Perez et al. (2006) and Miller et al. (2004), who concentrated mainly on the SW radiation-aerosol feedback. The local feedbacks before the cold front, driven by horizontal thermal gradients, neutralized each other and were thus much smaller in amplitude in TOTAL as compared to SW and LW. This shows that the timing of the storm, and whether it is primarily affected by the dust-short-wave or long-wave radiation interaction, is of great importance to understand how the dust layer impacts meteorology and vice-versa. In this case, the dust-radiation interaction had little impact on the synoptic situation, i.e. the motion of the highs and lows as well as the movement and intensity of the cold front that caused the storm. Cycling experiments, with a meteorological analysis that is provided by the NRT MACC-II system, are not the best tool, however, to assess the synoptic impact of dust-radiation interaction. Assimilation runs provide a better insight into this issue. 
Table 2. The level of $2 \mathrm{~m}$ temperature, RMSE of REF_ASSIM and TOTAL_ASSIM for forecast times $0,12,24,36$ and $48 \mathrm{~h}$, average for the period of 10 to 25 April 2012. Stations considered are Hurghada, Luxor, Kosseir, Siwa, Wadi el Natrun, Cairo, Port Said and Ras Sedr in Egypt, and Ben Gurion airport, close to Tel Aviv in Israel.

\begin{tabular}{lccccc}
\hline Forecast time & $0 \mathrm{~h}$ & $12 \mathrm{~h}$ & $24 \mathrm{~h}$ & $36 \mathrm{~h}$ & $48 \mathrm{~h}$ \\
\hline REF_ASSIM & 1.46 & 1.48 & 1.5 & 1.62 & 1.53 \\
\hline TOTAL_ASSIM & 1.32 & 1.49 & 1.43 & 1.6 & 1.58 \\
\hline
\end{tabular}

\section{Assimilation runs}

Figure 16 shows the differences between the experiments TOTAL_ASSIM and REF_ASSIM for $2 \mathrm{~m}$ temperature, $10 \mathrm{~m}$ wind speed, dust production and dust AOD at $550 \mathrm{~nm}$ for the runs starting at 00:00 UTC on 17 April 2012, 24 and $36 \mathrm{~h}$ forecasts. For $2 \mathrm{~m}$ temperature, the magnitude of the changes brought by interactive aerosol-radiation interaction was similar in the experiments with and without assimilation. This is true for both the SW and LW dust-meteorology feedbacks. However, the impact on surface winds and dust production was more important with assimilation runs. This different behaviour can be explained by the fact that the timescales involved were different for the surface temperature and for wind speed adjustments to the radiative forcings. The heat capacity of sand is low, which makes the thermal inertia of desert soils small as well; surface temperature adjusts quickly to a change in the radiative fluxes. As a consequence, the fact that the analysis takes dust-radiation interaction from an aerosol climatology or from interactive aerosols into account does not have such a large impact, since in any case surface temperature will adjust quickly to the radiative forcings during the forecast. However, for winds, the adjustment takes more time since the changes are driven by vertical and horizontal temperature gradients, and the changes concern the whole boundary layer (see Fig. 14). As a consequence, it appears that taking the interactive dust-radiation into account in the analysis of TOTAL_ASSIM through the first guess (the previous forecast used in the 4D-Var to build the initial conditions) enhanced the feedback between radiation and surface winds as compared to TOTAL. The weight of the first guess in the analysis was amplified by the fact that the dust storm of 17-18 April 2012 occurred in a region where both meteorological and total AOD observations are sparse.

The impact on dust production is clear: the difference between TOTAL_ASSIM and REF_ASSIM was more marked, at 00:00 and at 12:00 UTC, than the difference between TOTAL and REF (not shown). However, the feedbacks associated with dust-short-wave and long-wave radiation interaction, even if they were more intense as compared to TOTAL, appear to neutralize each other: in the dust storm, the difference in AOD seldom exceeded 0.1 between TOTAL_ASSIM
Table 3. Levels of $2 \mathrm{~m}$ temperature, bias of REF_ASSIM and TOTAL_ASSIM for forecast times $0,12,24,36$ and $48 \mathrm{~h}$, average for the period of 10 to 25 April 2012 over the same selection of weather stations as Table 2.

\begin{tabular}{lccccc}
\hline Forecast time & $0 \mathrm{~h}$ & $12 \mathrm{~h}$ & $24 \mathrm{~h}$ & $36 \mathrm{~h}$ & $48 \mathrm{~h}$ \\
\hline REF_ASSIM & -0.87 & -0.05 & -0.73 & 0.48 & -0.47 \\
\hline TOTAL_ASSIM & -0.65 & -0.18 & -0.58 & 0.2 & 0.26 \\
\hline
\end{tabular}

and REF_ASSIM. A few hundred kilometres east of the storm, the impact was not negligible, with dust AOD being reduced by 0.2 to 0.3 with TOTAL_ASSIM, at 00:00 and 12:00 UTC.

\subsection{Impact on the quality of $\mathbf{2} \mathrm{m}$ temperature forecasts by the MACC global system}

The previous sections showed that surface temperature was significantly affected by using interactive aerosols to compute the dust-radiation interaction. This sections aims to assess whether this impact improves the quality of $2 \mathrm{~m}$ temperature forecasts. Assimilation runs very close to the configuration used for the NRT global MACC-II system are used in this section.

In this section forecasts are evaluated for the period from 10 to 25 April 2012, over a selection of meteorological stations over Egypt and Israel, for runs starting at 00:00 UTC. Since the horizontal resolution was rather crude, several stations were not taken into account because of land-sea representativity problems. Tables 2 and 3 show the root-meansquare error (RMSE) and bias of the REF_ASSIM and TOTAL_ASSIM for forecast times ranging from 0 to $48 \mathrm{~h}$. The analysis of $2 \mathrm{~m}$ temperature was significantly improved both in terms of RMSE and bias, by up to 10 and $20 \%$ respectively. This shows that with assimilation runs, the impact of using prognostic aerosols' radiative effect is important for the analysis and for short-term forecasts. The $24 \mathrm{~h}$ forecasts also show an improvement of about $20 \%$ for the bias, and a smaller one for RMSE. The higher minimal temperatures associated with the dust-long-wave radiation interaction brought an improvement of both bias and RMSE for the analysis and the forecasts at 0,24 and $48 \mathrm{~h}$.

The 12 and $36 \mathrm{~h}$ forecasts showed no improvement of TOTAL_ASSIM compared to REF_ASSIM in terms of RMSE. The bias decreased significantly for both forecast times, which led to a smaller cold bias at $12 \mathrm{~h}$ forecast, and an improvement of the warm bias after $36 \mathrm{~h}$ of forecast time.

To sum up, the overall improvement brought by TOTAL_ASSIM was significant for the initial conditions and forecasts of $2 \mathrm{~m}$ temperatures. The positive impact on RMSE was smaller and smaller with forecast time, turning into a degradation for forecast times longer than $36 \mathrm{~h}$. This is prob- 

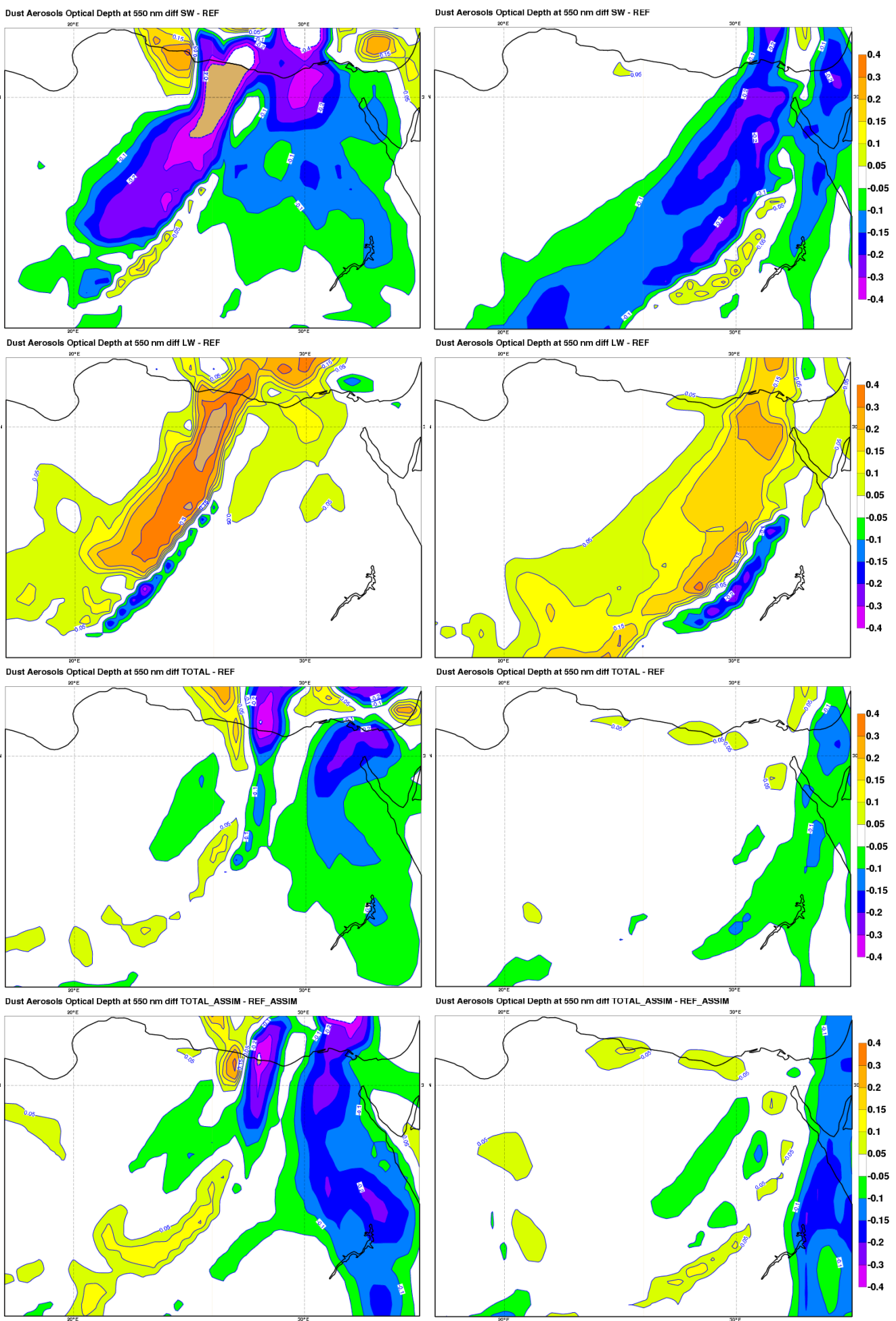

Figure 15. Simulations starting on 17 April 2012, $24 \mathrm{~h}$ forecast (left) and $36 \mathrm{~h}$ (right) forecast time. Difference of AOD at 550 nm, SW-REF (top), LW-REF (middle top), TOTAL-REF (middle bottom) and TOTAL_ASSIM-REF_ASSIM (bottom). 

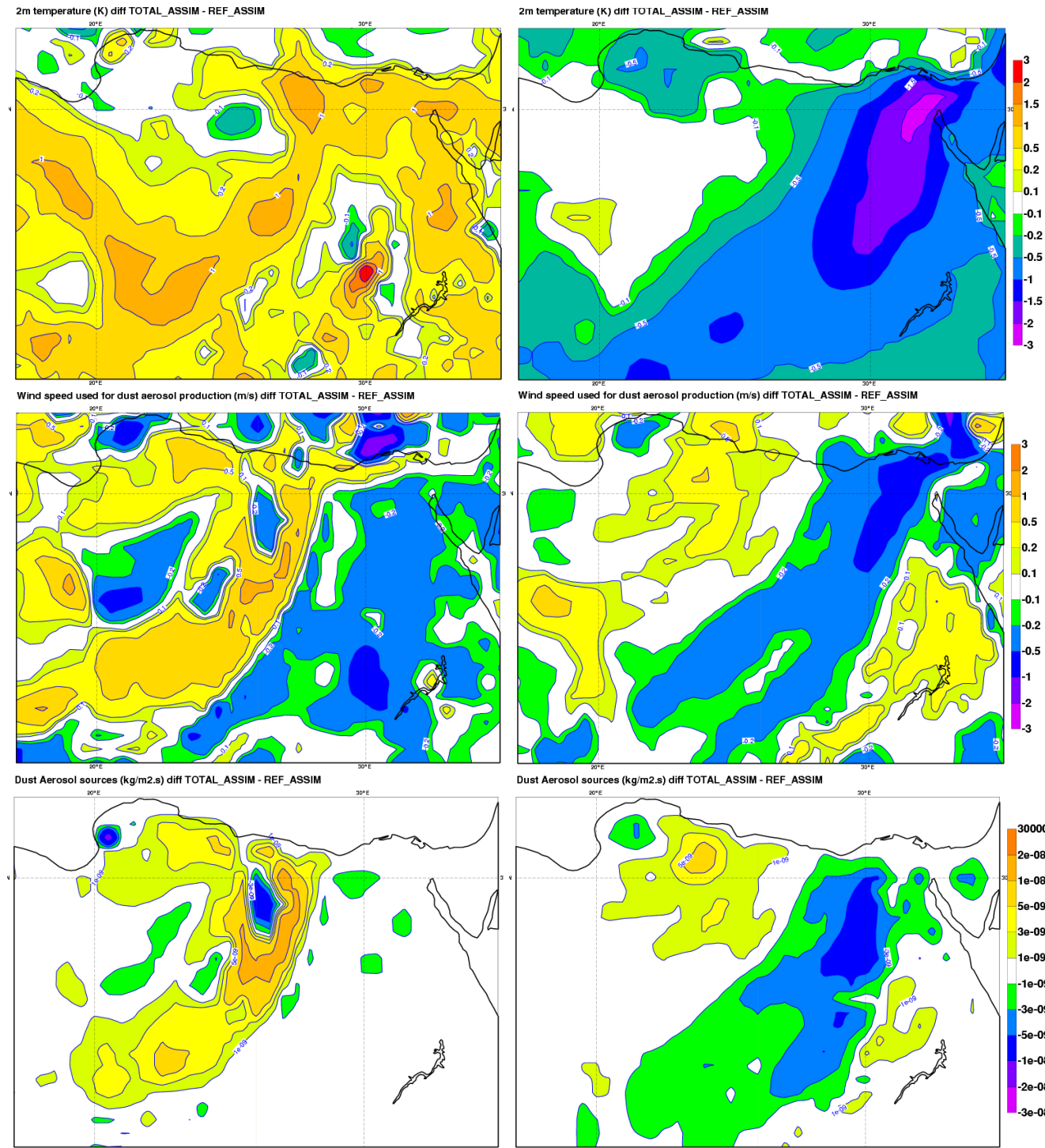

Dust Aerosol sources (kg/m2.s) diff TOTAL_ASSIM - REF_ASSIM

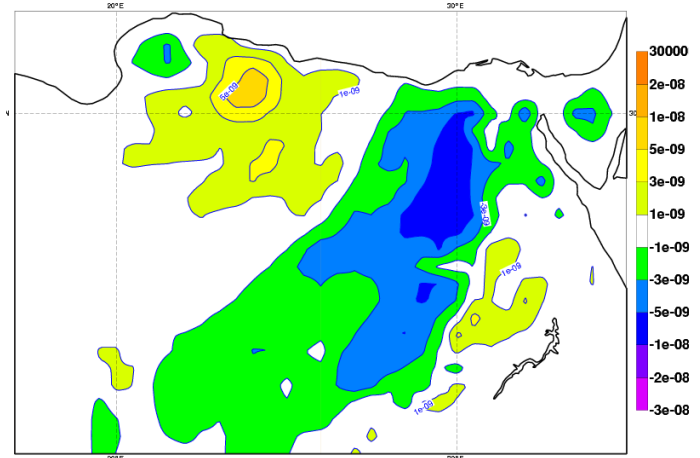

Figure 16. Simulations starting on 17 April 2012, $24 \mathrm{~h}$ forecast (left) and $36 \mathrm{~h}$ (right) forecast time. Difference of TOTAL_ASSIMREF_ASSIM for $2 \mathrm{~m}$ temperature (top), $10 \mathrm{~m}$ wind speed (middle) and dust production (bottom).

ably because the errors in the amount of dust and in the location/timing of the dust storm increased with forecast time.

\section{Summary and conclusions}

In this study we highlighted a series of interactions between aerosols and boundary layer meteorology, driven by the short-wave and long-wave radiative forcing of mineral dust. In the shortwave, lower maximum temperatures increased lower atmosphere stability, which brought in turn a decrease in wind speed and in dust production through saltation processes. Locally, at the edge of the dust plume, the short-wave forcing perturbed the horizontal temperature gradient and geostrophic winds associated with a cold front. Lo- cal increases in surface pressure gradient also brought local significant increases in surface geostrophic winds. These two processes led to sharp increases of surface wind and of local dust production.

The impact of the dust layer on long-wave radiation brought opposite feedbacks: warmer temperatures at night decreased the stability of the PBL, thus strengthening surface winds and dust emissions. Contrasted heating of the midboundary layer at night decreased the horizontal temperature gradient at the edge of the dust plume. Associated with lower pressure gradients, this brought lower geostrophic winds at the surface and higher, which in turn led to local decreases in wind speed and dust production.

The SW radiation-dust interaction was more pronounced than the LW radiation-dust for radiative fluxes and effi- 
ciency. For surface temperature and dust production, the two feedbacks were of a comparable amplitude. This highlights how important accurate forecasts of the timing of the storm are, since depending on the local time of the dust lifting episodes, the interactions between aerosol and boundary layer meteorology are of a very different nature.

The dust-boundary layer meteorology feedbacks were amplified in assimilation runs, because they were also taken into account in the initial conditions of both aerosols and temperature. Since the considered region does not have many observations of both temperature and total AOD from MODIS, the first guess had an unusually large relative contribution in the initial conditions. Although the synoptic situation was not much affected by the radiative forcing of the prognostic aerosols, we report a generally positive impact up to a $48 \mathrm{~h}$ lead time on the $2 \mathrm{~m}$ temperature and forecasts of surface radiative fluxes.

Acknowledgements. We thank NASA for providing the MODIS data, and the AERONET and BSRN projects for making their data freely and easily available. The authors also wish to thank Robin Hogan for his useful suggestions. This research was supported by the EU Seventh Research Framework Programme (MACC-II project, contract number 283576).

Edited by: M. Schulz

\section{References}

Ackerman, T. P. and Toon, O. B.: Absorption of visible radiation in atmosphere containing mixtures of absorbing and non-absorbing particles, Appl. Opt., 20, 3661-3667, 1981.

Ahn, H. J., Park, S. U., and Chang, L. S.: Effect of direct radiative forcing of Asian dust on the meteorological fields in east Asia during an Asian dust event period, J. Appl. Meteorol. Climatol., 46, 1655-1681, 2007.

Bellouin, N., Boucher, O., Haywood, J., and Shekar Reddy, M.: Global estimate of aerosol direct radiative forcing from satellite measurements, Nature, 438, 1138-1141, 2005.

Bellouin, N., Rae, J., Jones, A., Johnson, C., Haywood, J., and Boucher, O.: Aerosol forcing in the Climate Model Intercomparison Project (CMIP5) simulations by HadGEM2-ES and the role of ammonium nitrate, J. Geophys. Res., 116, D20206, doi:10.1029/2011JD016074, 2011.

Benedetti, A., Morcrette, J.-J., Boucher, O., Dethof, A., Engelen, R. J., Fisher, M., Flentje, H., Huneeus, N., Jones, L., Kaiser, J. W., Kinne, S., Mangold, A., Razinger, M., Simmons, A. J.. and Suttie, M.: Aerosol analysis and forecast in the European Centre for Medium-Range Weather Forecasts Integrated Forecast System: 2. Data assimilation, J. Geophys. Res., 114, D13205, doi:10.1029/2008JD011115, 2009.

Boucher, O., Pham, M., and Venkataraman, C.: Simulation of the atmospheric sulfur cycle in the LMD GCM: Model description, model evaluation, and global and European budgets, Note 23, 26 pp., Inst. Pierre-Simon Laplace, Paris, France, 2002.
Carlson, T. N. and Benjamin, S. G.: Radiative heating rates for Saharan dust, J. Atmos. Sci., 37, 193-213, 1980.

Choi, J.-O. and Chung, C.-E.: Sensitivity of aerosol direct radiative forcing to aerosol vertical profile, Tellus B, 66, 24376, doi:10.3402/tellusb.v66.24376, 2014.

Fiedler, S., Schepanski, K., Heinold, B., Knippertz, P., and Tegen, I.: Climatology of nocturnal low-level jets over North Africa and implications for modeling mineral dust emission, J. Geophys. Res.-Atmos., 118, 6100-6121, doi:10.1002/jgrd.50394, 2013.

Fouquart, Y., Bonnel, B., Brogniez, G., Buriez, J. C., Smith, L., Morcrette, J. J., and Cerf, A.: Observations of Saharan Aerosols: Results of ECLATS Field Experiment. Part II: Broadband Radiative Characteristics of the Aerosols and Vertical Radiative Flux Divergence, J. Clim. Appl. Meteorol., 26, 38-52, doi:10.1175/1520-0450(1987)026<0038:OOSARO>2.0.CO;2, 1987.

Freitas, S.: Evaluating aerosols impacts on Numerical Weather Prediction: A WGNE/WMO Initiative, Conference paper, available at: http://www.researchgate.net/publication/ 273258328_Evaluating_aerosols_impacts_on_Numerical_

Weather_Prediction_A_WGNEWMO_Initiative, last access: 4 September 2015.

Ginoux, P., Chin, M., Tegen, I., Prospero, J., Holben, B. N., Dubovik, O., and Lin, S.-J.: Sources and distributions of dusts simulated with the GOCART model, J. Geophys. Res., 106, 20255-20274, 2001.

Han, Z., Li, J., Guo, W., Xiong, Z., and Zhang, W.: A study of dust radiative feedback on dust cycle and meteorology over East Asia by a coupled regional climate-chemistry-aerosol model, Atmos. Environ., 68, 54-63, 2013.

Haywood, J. M., Osborne, S. R., Francis, P. N., Kiel, A., Formenti, P., Andreae, M. O., and Kaye, P. H.: The mean physical and optical properties of regional haze dominated by biomass burning aerosol measured from the C-130 aircraft during SAFARI 2000 , J. Geophys. Res., 108, 8473, doi:10.1029/2002JD002226, 2003.

Heimo, A., Vernez, A., and Wasserfallen, P.: Baseline Surface Radiation Network (BSRN). Concept and Implementation of a BSRN Station, WMO/td-no. 579, World Meteorological Organization,Geneva, Switzerland, 1993.

Heinold A., Tegen, I., Schepanski, I., and Hellmuth, O. Dust radiative feedback on Saharan boundary layer dynamics and dust mobilization, Geophys. Res. Lett., 35, L20817, doi:10.1029/2008GL035319, 2008.

Heinold, B., Knippertz, P., Marsham, J. H., Fiedler, S., Dixon, N. S., Schepanski, K., Laurent, B., and Tegen, I.: The role of deep convection and nocturnal low-level jets for dust emission in summertime West Africa: Estimates from convectionpermitting simulations, J. Geophys. Res.-Atmos., 118, 1-16, doi:10.1002/jgrd.50402, 2013.

Heinold, B., Knippertz, P., and Beare, R. J.: Idealized large-eddy simulations of nocturnal low-level jets over subtropical desert regions and implications for dust-generating winds, Q. J. Roy. Meteor. Soc., 141, 1740-1752, doi:10.1002/qj.2475, 2015.

Helmert, J., Heinold, B., Tegen, I. Hellmuth, O., and Wendisch, M.: On the direct and semi-direct effect of Saharan dust over Europe: A case study, J. Geophys. Res., 112, D13208, doi:10.1029/2006JD007444, 2007.

Highwood, E. J., Haywood, J. M., Silverstone, M. D., Newman, S. M., and Taylor, J. P.: Radiative properties and direct effect 
of Saharan dust measured by the C-130 aircraft during Saharan Dust Experiment (SHADE): 2. Terrestrial spectrum, J. Geophys. Res., 108, 8578, doi:10.1029/2002JD002552, 2003.

Holben, B. N., Eck, T. F., Slutsker, I., Tanré, D., Buis, J. P., Setzer, A., Vermote, E., Reagan, J. A., Kaufman, Y., Nakajima, T., Lavenu, F., Jankowiak, I., and Smirnov, A.: AERONET - A federated instrument network and data archive for aerosol characterization, Remote Sens. Environ., 66, 1-16, 1998.

Hollingsworth, A., Engelen, R. J., Textor, C., Benedetti, A., Boucher, O., Chevallier, F., Dethof, A., Elbern, H., Eskes, H., Flemming, J., Granier, C., Kaiser, J. W., Morcrette, J.-J., Rayner, P., Peuch, V.-H., Rouil, L., Schultz, M. G., and Simmons, A. J.: Toward a Monitoring and Forecasting System For Atmospheric Composition: The GEMS Project, B. Am. Meteorol. Soc., 89, 1147-1164, 2008.

Holton, J. R.: An Introduction to Dynamic Meteorology, New York, Academic Press, ISBN 0-12-354015-1, 2004.

Hoose, C. and Möhler, O.: Heterogeneous ice nucleation on atmospheric aerosols: a review of results from laboratory experiments, Atmos. Chem. Phys., 12, 9817-9854, doi:10.5194/acp-12-98172012, 2012.

Huneeus, N., Schulz, M., Balkanski, Y., Griesfeller, J., Prospero, J., Kinne, S., Bauer, S., Boucher, O., Chin, M., Dentener, F., Diehl, T., Easter, R., Fillmore, D., Ghan, S., Ginoux, P., Grini, A., Horowitz, L., Koch, D., Krol, M. C., Landing, W., Liu, X., Mahowald, N., Miller, R., Morcrette, J.-J., Myhre, G., Penner, J., Perlwitz, J., Stier, P., Takemura, T., and Zender, C. S.: Global dust model intercomparison in AeroCom phase I, Atmos. Chem. Phys., 11, 7781-7816, doi:10.5194/acp-11-7781-2011, 2011.

Jish Prakash, P., Stenchikov, G., Kalenderski, S., Osipov, S., and Bangalath, H.: The impact of dust storms on the Arabian Peninsula and the Red Sea, Atmos. Chem. Phys., 15, 199-222, doi:10.5194/acp-15-199-2015, 2015.

Knippertz, P.: Dust emissions in the West African heat trough: the role of the diurnal cycle and of extratropical disturbances, Meteorol. Z., 17, 553-563, doi:10.1127/0941-2948/2008/0315, 2008.

Koch, D. and Del Genio, A. D.: Black carbon semi-direct effects on cloud cover: review and synthesis, Atmos. Chem. Phys., 10, 7685-7696, doi:10.5194/acp-10-7685-2010, 2010.

Liao, H. and Seinfeld, J. H.: Radiative forcing by mineral dust aerosols: sensitivity to key variables, J. Geophys. Res, 103, 31637-31645, doi:10.1029/1998JD200036, 1998.

Lyubansky, V.: Meteorological synoptical observations from station Sede Boqer (2012-01). The Jacob Blaustein Institutes for Desert Research, Sede Boqer, doi:10.1594/PANGAEA.802681, 2012.

Marticorena, B. and Bergametti, G.: Modeling the atmospheric dust cycle: 1. Design of a soil-derived dust emission scheme, J. Geophys. Res., 100, 2156-2202, doi:10.1029/95JD00690, 1995.

Miller, R. L., Perlwitz, J., and Tegen, I.: Feedback upon dust emission by dust radiative forcing through the planetary boundary layer, J. Geophys. Res., 109, D24209, doi:10.1029/2004JD004912, 2004.

Miller, R. L., Knippertz, P., Pérez García-Pando, C., Perlwitz, J. P., and Tegen, I.: Impact of dust radiative forcing upon climate, in: Mineral Dust: A Key Player in the Earth System, edited by: Knippertz, P. and Stuut, J.-B. W., Springer, 327-357, doi:10.1007/978-94-017-8978-3_13, 2014.
Mimouni, M.: Basic measurements of radiation at station Tamanrasset (2013-09), National Meteorological Office of Algeria, doi:10.1594/PANGAEA.822372, 2013.

Mishchenko, M. I., Travis, L. D., Kahn, R. A., and West, R. A.: Modeling phase functions for dustlike tropospheric aerosols using a shape mixture of randomly oriented polydisperse spheroids, J. Geophys. Res., 102, 16831-16847, 1997.

Morcrette, J.-J., Boucher, O., Jones, L., Salmond, D., Bechtold, B., Beljaars, A., Benedetti, A., Bonet, A., Kaiser, J. W., Razinger, M., Schulz, M., Serrar, S., Simmons, A. J., Sofiev, M., Suttie, M., Tompkins, A. M., and Untch, A.: Aerosol analysis and forecast in the European Centre for Medium-Range Weather Forecasts Integrated Forecast System: Forward modeling, J. Geophys. Res., 114, D06206, doi:10.1029/2008JD011235, 2009.

Mulcahy, J. P., Walters, D. N., Bellouin, N., and Milton, S. F.: Impacts of increasing the aerosol complexity in the Met Office global numerical weather prediction model, Atmos. Chem. Phys., 14, 4749-4778, doi:10.5194/acp-14-4749-2014, 2014.

Myhre, G. and Stordal, F.: Global sensitivity experiments of the radiative forcing due to mineral aerosols, J. Geophys. Res., 106, 18193-18204, 2001.

Myhre, G., Grini, A., Haywood, J. M., Stordal, F., Chatenet, B., Tanré, D., Sundet, J. K., and Isaksen, I. S. A.: Modeling the radiative impact of mineral dust during the Saharan Dust Experiment (SHADE) campaign, J. Geophys. Res., 108, 8579, doi:10.1029/2002JD002566, 2003.

Nickovic, S., Kallos, G., Papadopoulos, A., and Kakaliagou, O.: A model for prediction of desert dust cycle in the atmosphere, J. Geophys. Res., 106, 18113-18129, doi:10.1029/2000JD900794, 2001.

Niemand, M., Möhler, O., Vogel, B., Vogel, H., Hoose, C., Connolly, P., Klein, H., Bingemer, H., DeMott, P., Skrotzki, J., and Leisner, T.: A Particle-Surface-Area-Based Parameterization of Immersion Freezing on Desert Dust Particles, J. Atmos. Sci., 69, 3077-3092, doi:10.1175/JAS-D-11-0249.1, 2012.

Painemal, D. and Zuidema, P.: The first aerosol indirect effect quantified through airborne remote sensing during VOCALSREx, Atmos. Chem. Phys., 13, 917-931, doi:10.5194/acp-13917-2013, 2013.

Pérez, C., Nickovic, S., Pejanovic, G., Baldasano, J. M., and Özsoy, E.: Interactive dust-radiation modeling: A step to improve weather forecast, J. Geophys. Res., 111, D16206, doi:10.1029/2005JD006717, 2006.

Peuch, V.-H. and Engelen, R. J.: Towards and operational GMES Atmosphere Monitoring Service, ECMWF Newsletter No. 132, 20-25, 2012.

Reddy, M. S., Boucher, O., Bellouin, N., Schulz, M., Balkanski, Y., Dufresne J.-L., and Pham, M.: Estimates of global multicomponent aerosol optical depth and direct radiative perturbation in the Laboratoire de Meteorologie Dynamique general circulation model, J. Geophys. Res., 110, D10S16, doi:10.1029/2004JD004757, 2005.

Rodwell, M. J. and Jung, T.: Understanding the local and global impacts of model physics changes: an aerosol example, Q. J. Roy. Meteorol. Soc., 134, 1479-1497, 2008.

Shi, Y., Zhang, J., Reid, J. S., Hyer, E. J., and Hsu, N. C.: Critical evaluation of the MODIS Deep Blue aerosol optical depth product for data assimilation over North Africa, Atmos. Meas. Tech., 6, 949-969, doi:10.5194/amt-6-949-2013, 2013. 
Sokolik, I. N., Androvna, A., and Johnson, T. C.: Complex refractive index of atmospheric dust aerosols, Atmos. Environ., 27A, 2495-2502, 1993.

Sokolik, I. N., Toon, O. B., and Bergstrom, R. W.: Modelling the radiative characteristics of airborne mineral aerosols at infrared wavelengths, J. Geophys. Res., 103, 8813-8826, 1998.

Spyrou, C., Kallos, G., Mitsakou, C., Athanasiadis, P., Kalogeri, C., and Iacono, M. J.: Modeling the radiative effects of desert dust on weather and regional climate, Atmos. Chem. Phys., 13, 54895504, doi:10.5194/acp-13-5489-2013, 2013.

Stanelle, T., Vogel, B., Vogel, H., Bäumer, D., and Kottmeier, C.: Feedback between dust particles and atmospheric processes over West Africa during dust episodes in March 2006 and June 2007, Atmos. Chem. Phys., 10, 10771-10788, doi:10.5194/acp10-10771-2010, 2010.

Sun, Y. L., Wang, Z. F., Fu, P. Q., Yang, T., Jiang, Q., Dong, H. B., Li, J., and Jia, J. J.: Aerosol composition, sources and processes during wintertime in Beijing, China, Atmos. Chem. Phys., 13, 4577-4592, doi:10.5194/acp-13-4577-2013, 2013.

Tegen, I. and Lacis, A. A.: Modeling of particle size distribution and its influence on the radiative properties of mineral dust aerosol J. Geophys. Res., 101, 19237-19244, doi:10.1029/95JD03610, 1996.

Tegen, I., Hoorig, P., Chin, M., Fung, I., Jacob, D., and Penner, J.: Contribution of different aerosol species to the global aerosol extinction optical thickness: Estimates from model results, J. Geophys. Res., 102, 23895-23915, 1997.

Tompkins, A. M., Cardinali, C., Morcrette, J. J., and Rodwell, M.: Influence of aerosol climatology on forecasts of the African Easterly Jet, Geophys. Res. Lett., 32, L10801, doi:10.1029/2004GL022189, 2005.
Van de Wiel, B., Moene, A., Steeneveld, G., Baas, P., Bosveld, F., and Holtslag, A.: A Concep- tional view on Inertial Oscillations and Nocturnal Low-Level Jets, J. Atmos. Sci., 67, 2679-2689, doi:10.1175/2010JAS3289.1, 2010.

Woodward, S.: Modeling the atmospheric life cycle and radiative impact of mineral dust in the Hadley Centre climate model, J. Geophys. Res., 106, 18155-18166, doi:10.1029/2000JD900795, 2001.

World Meteorological Organization (WMO): Report of the Experts Meeting on Aerosols and Their Climatic Effects, WCP-55, Geneva, Switzerland, 1983.

Yu, H., Kaufman, Y. J., Chin, M., Feingold, G., Remer, L. A., Anderson, T. L., Balkanski, Y., Bellouin, N., Boucher, O., Christopher, S., DeCola, P., Kahn, R., Koch, D., Loeb, N., Reddy, M. S., Schulz, M., Takemura, T., and Zhou, M.: A review of measurement-based assessments of the aerosol direct radiative effect and forcing, Atmos. Chem. Phys., 6, 613-666, doi:10.5194/acp-6-613-2006, 2006.

Yu, H., Chin, M., Yuan, T., Bian, H., Remer, L. A., Prospero, J. M., Omar, A., Winker, D., Yang, Y., Zhang, Y., Zhang, Z., and Zhao, C.: The fertilizing role of African dust in the Amazon rainforest: A first multiyear assessment based on data from Cloud-Aerosol Lidar and Infrared Pathfinder Satellite Observations, Geophys. Res. Lett., 42, 1984-1991, doi:10.1002/2015GL063040, 2015.

Zhang, J. K., Sun, Y., Liu, Z. R., Ji, D. S., Hu, B., Liu, Q., and Wang, Y. S.: Characterization of submicron aerosols during a month of serious pollution in Beijing, 2013, Atmos. Chem. Phys., 14, 2887-2903, doi:10.5194/acp-14-2887-2014, 2014. 